Portland State University

PDXScholar

1974

\title{
The Positive Aspects of a Program of Participation in a Retirement Center
}

Yvonne Burke

Portland State University

Follow this and additional works at: https://pdxscholar.library.pdx.edu/open_access_etds

Part of the Social Work Commons

Let us know how access to this document benefits you.

\section{Recommended Citation}

Burke, Yvonne, "The Positive Aspects of a Program of Participation in a Retirement Center" (1974). Dissertations and Theses. Paper 1725.

https://doi.org/10.15760/etd.1724

This Thesis is brought to you for free and open access. It has been accepted for inclusion in Dissertations and Theses by an authorized administrator of PDXScholar. Please contact us if we can make this document more accessible: pdxscholar@pdx.edu. 
THE POSITIVE ASPECTS OF A PROGRAM OF PARTICIPATION

IN A RETIREMENT CENTER

\begin{abstract}
by
Yvonne Burke

A report submitted in partial fulfillment of the requirements for the degree of
\end{abstract}

MASTER OF SOCIAL WORK

Portland State University 197.4 
APPROVED:

ADA K. WILSON, Practicum Advisor

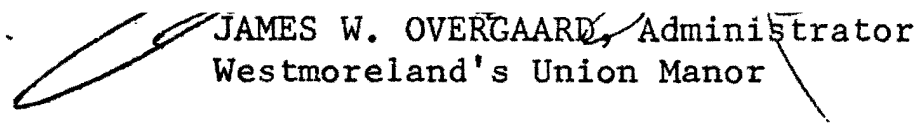

April 1, 1974 


\section{ACKNOWLEDGEMENTS}

I am grateful to many interested people for their encouragement and assistance in the development of this practicum.

I especially wish to thank the following people:

Mr. James W. Overgaard, Manager of Westmoreland's Union Manor, who frankly spelled out his ground rules for research, shared his philosophy and knowledge about the needs of the elderly and various alternatives for meeting those needs, supplied basic information about the Manor, its policies and funding--then left me strictly alone to research in any direction $I$ wished and to draw my own conclusions.

Dr. Frank Miles, professor at the School of Social Work, who helped develop the format for the study.

Ms. Ada K. Wilson, my advisor, who gave so freely of her time to discuss the Manor and its program and to read rough drafts. Her suggestions and advice were most helpful.

And finally, my very special thanks to the people of Westmoreland's Union Manor who so graciously shared their lives with me for awhile. 
TABLE OF CONTENTS

PAGE

ACRNOWLEDGMENTS. . . . . . . . . . . . . .

CHAPTER

I INTRODUCTION . . . . . . . . . . . . .

II METHODOLOGY. . . . . . . . . . . . . 4

III BACKGROUND ............... . . . 10

The Setting. . . . . . . . . . 10

The Institution. . . . . . . . . 12

The Staff. . . . . . . . . . 16

The Residents. . . . . . . . . . 19

IV PROGRAM. . . . . . . . . . . . . . 22

Development. . . . . . . . . 22

Philosophy ............. . . 22

Elements . . . . . . . . . . 28

Operation.............. 52

Assessment . . . . . . . . . 54

V CONCLUSIONS. . . . . . . . . . . 57

Positives. . . . . . . . . 57

Negatives. . . . . . . . . 59

Limitations. . . . . . . . . 60

The Lessons for Social Work. . . . . . 60 
APPENDIX A: Responses to Questions . . . . . . 70

APPENDIX B: Civic Club Financial Report. . . . . . 79

APPENDIX C: Minutes of Civic Club Meeting. . . . . . 81

APPENDIX D: Minutes of Men's Club Meetings . . . . 86

APPENDIX E: High Lights of 1973. . . . . . . . . 90

APPENDIX F: Civic Club By-Laws . . . . . . . . 95

APPENDIX G: Considerations in Planning Housing for

Independent Elderly: An Administrator's

view .............. 100 
CHAPTER I

\section{INTRODUCTION}

During my first year's field placement in graduate school, I worked in a Mental Health and Family'Service Center near Portland, Oregon. Among other duties at the Center, I was involved with several elderly clients and their families in a convalescent home, as well as with elderly clients who lived in their own homes either alone or with their marriage partner. Most of these people had led active lives during their eariy retirement years, only to fall prey to deficits connected with the aging process in later years.

These deficits often made it difficult, if not impossible, to drive their cars if they still had them, or to use public transportation. Some lived a few blocks, or more, from a bus stop but were unable to walk the distance required to catch the bus; families were either nonexistent or lived distances away; and neighborhoods had changed--friends and acquaintances had died or moved away, and new, often young families with their own interests had moved in. Consequently, my clients had become increasingly more lonely and isolated and evermore concerned with their disabilities.

They were also concerned with the cost of maintaining their homes when they could no longer perform necessary maintenance and repairs, and they worried about their inability to maintain their homes 
as they "used to." There was the added concern of "What if something happens to me and no one is there to call for help?" Yet, I found many of these people could not and would not allow themselves to consider noving to a retirement home.

None of this group could afford the large down payment required in most retirement homes, though many. could have managed the rent at a moderately priced place like the Manor. Some would have been eligible for low-income housing, yet refused because of the stigma they saw attached to living in a "low-cost housing project." And many talked vehemently of their feeling that moving to a retirement home would mean a loss of independence, and that above all they could not tolerate.

As a result of this exposure and after reading a statement in an article in the Northwest Magazine Section of the Sunday Oregonian (June 17, 1973 , p. 10) to the effect that "she called retirement homes 'a whole new bunch of ghettoes, which will return to haunt us in the years to come," I I decided to make a study of a moderately priced retirement home the subject of my research practicum.

Short of becoming a full-time resident of the home, I planned to spend considerable time there, to share in activities at all hours of the day and evening, to talk with residents and staff, and to observe generally the tone and quality of life in the home.

Having heard in the past from friends who lived in and near the Westmoreland community, as well as from other health care professionals, about Westmoreland's. Union Manor's social program, its policy of 
no down payment on admission, and the income range among the residents, I decided to contact the Manager to request permission to do my study there. 
CHAPTER II

METHODOLOGY

When I contacted the Manager of the Manor to request permission to do my practicum there, he was most cordial and felt that I could "take off in almost any direction and write a book" about the Manor and its residents. However, the residents had requested him not to allow further researchers in because they felt "researched out." He was, however, sympathetic to my desire to study this particular type of home--perhaps because he shares my interest in older people who lack resources to live where they can enjoy active involved lives up to their full capacity and desire to do so. (As the reader is probably aware, many retirement homes require large initial down payments, as well as monthly charges for services, thus making them prohibitive for many elderly people.)

Therefore, he agreed that I could visit in the home freely to share in and observe activities. He agreed further that I could tell the residents I was interested in learning more about retirement home living and activities and the advantages and disadvantages of retirement home living as they saw them. However, I was not to use questionnaires or make any attempt to interview a random sample of the residents. 
Thus, this became a participant-observation study. I hoped as residents became acquainted with me and learned what $I$ was doing they would enjoy sharing opinions about the advantages and disadvantages of retirement home living freely and openly. I also hoped some would invite me to visit in their apartments so I could develop a valid sense of the quality of their lives and how they used their time. The Manager introduced me at a Civic Club meeting in early August, after which there was a wedding reception for a recently married couple who had met since coming to live at the Manor. (Incidentally, this is the sixth marriage in the Manor since its opening.)

I spoke briefly, telling something of myself, my background, and my reasons for being there. After the formal meeting ended and during the reception, I was pleasantly surprised when five people introduced themselves, indicated their interest in what I was doing, and invited me to visit in their apartments. Others were cordial, and one lady in particular who is well known to the residents introduced me to several different groups. Thus, I was off to a good start.

After a brief time when I solicited material from the U.S. Department of Housing and Urban Development on the 202 and 236 housing programs, I spent two full weeks at the Manor, thinking it would be helpful if I became as familiar as part of the woodwork. I was there from early morning till late at night--sitting in the restaurant casually visiting with people, watching pool games, sitting on porch 
swings rocking and chatting, talking with people in the laundry room as they did their washing, joining an impromptu song fest in the meeting room one morning when two ladies--one playing the organ and the other the piano--were playing catchy tunes for fun, and visiting folks who invited me to visit in their apartments.

During this two-week period I also accompanied a bus load of residents on an all-day trip to the Oregon State Fair, visited a Men's Club meeting and spoke of my reasons for being at the Manor, visited a Tri-Chem embroidery class, and daily received new invitations to visit with people in their apartments.

These invitations often stemmed from a casual chat in which they would mention some favorite handwork such as hairpin lace, painting, or knitting afghans, and as they realized I was truly interested in what they were doing, they would invite me to "come on up and see my apartment, and I'11 show you what I'm doing now." In all cases during the visit there was discussion of questions $I$ had about retirement home living as well (see Appendix A).

These people then introduced me to new people whom they thought I.would enjoy meeting, i.e., a friend who had some special handicraft. In other cases, they introduced me to people they realized would present a different view of life at the Manor, i.e., someone who is able to participate in few of the activities because of physical problems.

These were two weeks well spent because many people who at first were reserved began to take me for granted and in most cases began to 
relax their guard a bit. Also, as I met the chairmen of various social committees, they seemed pleased and eager to share with me the accomplishments of their committees and how they have contributed to the quality of life at the Manor.

After visiting some twenty residents in their apartments while concurrently visiting with others during various activities, it became apparent that the individual visits had been of value in getting started and becoming well acquainted with a few people. These people then sort of adopted and sponsored me. However, the individual visits were extremely time consuming, averaging one and one-half to two hours each, and the information I was receiving in private visits and in individual chats during activities or casual encounters was falling into a similar pattern. Therefore, though I still accepted invitations to visit in apartments when offered, I quit encouraging them as I spoke to groups.

During these visits and chats with residents, I had questions - in my mind that I interjected into the conversation at some point. These were asked in various ways but basically were as follows (see Appendix A for responses):

1. What were your reasons for moving into a retirement home?

2. How does this location work out for you?

3. How much interaction is there between Manor residents and the community?

4. How often do you eat in the dining room?

5. How do you spend your leisure time? Have you started new activities since coming here to live, or are you continuing activities you enjoyed before coming here? 
6. Do you feel cut off from your family and friends? (This question was asked in various ways, hoping to avoid the function of denial.)

7. What advantages do you see in retirement home living?

8. What disadvantages have you found in retirement home living?

9. Some people feel one may lose his independence if he moves to a retirement home. What do you think about that?

As I talked with residents and observed the high degree of interaction in this home, I became increasingly aware that the social program, both formal and informal, seemed to be the primary basis for it. Thus, I decided to focus my study on the social program itself--how it is set up, the mechanics of how it is run, who is involved, and approximately how many residents are involved in each activity.

I placed a note on the bulletin board as follows:

Since coming to live at Westmoreland's Union Manor, have you started new activities you didn't have time, or perhaps opportunity, to try before? Or, are you having time now to do more of something you always enjoyed doing--reading, cooking, painting, playing pool, sewing, traveling, socializing, resting; etc.?

If you would enjoy sharing your views on retirement home living and leisure-time activities of people over age sixtytwo, please call me at any time of the day or evening. I'd like to come and visit with you.

I also requested the editor of the Manor News and Views to

include the following note in the newspaper:

Yvonne Burke, who will be visiting a day or two a week at the Manor during the next few months, describes herself as an "older" graduate student in social work. (She started college seven years ago at the age of forty-three and has three 
grandchildren.) She is interested in learning more about retirement home living and leisure-time activities of people over sixty-two.

If you have time and would enjoy talking with Yvonne, please call her at like to come and visit with you. any day or evening. She'd

To my surprise, not one resident in the Manor ever responded to the above notes by calling on the telephone to ask me to visit or to discuss activities. However, many mentioned that they had read the notes and "thought the next time. I saw you'I'd let you know I'm interested in what you're doing and would enjoy visiting with you."

I purposely contacted committee and club officers--a few by telephone and others as I met them at various activities--to ask if they would have time to share information about their specific group or function with me. All these people responded enthusiastically, gave freely of their time, and went into considerable detail as they told me of their responsibilities, some of the problems they encounter, and what their specific group has accomplished for the Manor and its residents.

It is my hope that by presenting this program in considerable detail, other managers and residents of retirement homes may gain ideas and become newly aware of the advantages of a planned, coordinated resident-manager social program and that this study may be of aid in implementing such a program. This study might be useful as well for social workers working with elderly clients and their families to help in allaying their fears of moving to a retirement home. 
CHAPTER III

BACKGROUND

I. THE SETTING

Westmoreland's Union Manor is located on seven acres of land adjacent to the southeast Portland residential area of Westmoreland. The setting appears tranquil and park-like despite its location near a busy four-lane freeway. Several factors contribute to this tranquil park-1ike setting: there are trees which partly screen the property from the freeway, there is a year-round creek which meanders the full length of the property between the building and the freeway and which is populated with several families of Mallard ducks plus a seagul1 or two, and there are spacious lawns bordered by shrubs and flower beds.

The land is next to Westmoreland Park (through which Crystal Springs Creek continues meandering), and is just across the freeway from. Eastmoreland public golf course and the American Rhododendron Society test gardens--all of which enhance the setting and add many recreational opportunities.

Eight blocks away in the Westmoreland shopping center are shops, restaurants, a movie theater, and a bank. Downtown Portland or the large Lloyd shopping center is a few minutes away by bus. 
And the city bus stops at the front door of the Manor. Residents can ride the bus for ten cents from $9 \mathrm{a} . \mathrm{m}$. to $3 \mathrm{p} . \mathrm{m}$. weekdays and free of charge after 7 p.m. and on weekends and holidays.

The Westmoreland community is made up of moderately priced homes, usually very nicely maintained. The population is primarily working class with a few professional people. This "mix" is similar to the population of the Manor and may have contributed to the harmonious relationship existing between the Manor and the community. However, I observed minimal interaction, other than in the business district, between Manor residents and the community. And residents of both Manor and community verified this. A few community people do eat dinner occasionally, particularly on Sundays, in the Manor restaurant (the Gourmet Kitchen); several residents in the Manor are involved with the Loaves and Fishes program at a local church and serve there one day each month; occasionally a local piano-violin team, also elderly, entertains at Manor parties; and the Manor residents provide trick-or-treat material for community children on Halloween.

The Westmoreland community is fairly close knit, with a weekly community newspaper, the Sellwood-Moreland Bee, to wich the Manor contributes news regularly. The community also has a strong booster group in the Sellwood-Moreland Improvement League or SMILE organization.

An additional contributing factor to acceptance of the Manor in the community may be that originally the seven acres of land on 
which the Manor stands was leased by a large store chain intending to build a store there. However, residents of the community persistently voted down a requested zone change to commercial property, thus making it impossible for the store to be built. Finally, the zone change was approved for the Manor, and construction was completed seven years ago in October, 1966.

\section{THE INSTITUTION}

The Manor, as it is called, was sponsored by sixteen local trade unions--primarily the building trades--which formed a nonprofit corporation and applied for a direct government loan under the federally mortgaged housing program (Section-202).

This is a fifty-year loan at three and three-quarters per cent interest. When the loan is repaid, rents will be adjusted accordingly, as rents are based on total expenses for each year divided by the number of units in the building. No initial lump-sum payment is required. Monthly rents are presently $\$ 135$ for a one-bedroom apartment and $\$ 100$ for a studio apartment.

According to stipulations of the federally mortgaged housing program, there can be no profit to the Board of Directors or anyone else from this project. And, in the event the building is sold, the monies must either be given to a charitable organization, or the building and land itself must be given to a charitable organization.

Thus, the home is a monument to Labor in that Labor is providing housing for its own retired people--they've built it in their own behalf. However, residence is not limited solely to union members. 
The building is of concrete construction throughout and is designed in an attractive "S" shape. This "S" shape is designed for added strength in the structure; however, it also contributes to the total fluidity of the landscape, as it blends with the contours of the acreage and the creek.

The building was designed for convenience. There are two automatic elevators, no thresholds on inside doors, chrome hand rails in bathrooms, and there is twenty-four hour hot-water heat controlled individually in each apartment. There is central air conditioning for summer comfort as well.

There are 300 apartments in the building: 96 one-bedroom and 204 studio apartments on six floors. The apartments are attractive and quite spacious with large windows on the living room side. Each apartment has its own kitchen and outside balcony. The views from the balconies are pleasant as they look out over surrounding parks, golf course, and over the attractive Westmoreland community to the hills surrounding the city beyond. Drapes, wall-to-wall carpeting, ranges, and small refrigerators are furnished. Studio apartments have showers only, and one-bedroom apartments have tubs.

The first floor houses a variety of facilities: . beauty shop with a full-time operator; poolroom with seating space for spectators; hobby room with a large round table and chairs used for games, sewing, and painting classes; meeting room used for vesper services and smaller gatherings; large laundry room equipped with washers and dryers; a store containing groceries, drugs, and sundries; the lobby 
furnished with comfortable furniture; business offices; restrooms; a large multipurpose room at the end of the building which can be divided by folding doors; and a large kitchen.

One of the special things about the Manor is the care that was given to design and furnishings so that utilitarian purposes and attractiveness are melded instead of working at cross-purposes.

For example, the hobby room has an attractive planter and cupboards along two walls for storage of materials used there, e.g., sewing materials and supplies. And it is furnished with a television set and comfortable davenport and chairs as weli as the large round table used for classes and crafts. The meeting room is equipped with folding doors which make it possible to divide it into two even smaller rooms, and it contains both an organ and a piano. This room also houses a small library.

The large multipurpose room which occupies the end of the building will seat up to 400 people for large dinners and parties. One end of this room contains the dining room, kitchen, and serving area. The dining room is a pleasant spot. There are a few tables suitable for two to four people and several larger tables seating eight people. This arrangement encourages interaction among residents as anyone sits anywhere and is almost guaranteed not to eat alone if he sits at one of the larger tables. In addition, one of the cooks brings flowers from her home in season, and one resident takes responsibility for arranging them for each table and keeping them watered. 
The other end of the multipurpose room is used for meetings and parties and contains a newly purchased grand piano and a juke box. This room is a gathering spot--almost any time of day one may see a couple or two dancing to music from the juke box or a foursome playing bridge; and it is a convenient meeting place preliminary to sharing a cup of coffee or meeting for lunch.

There are floor-to-ceiling windows on both sides of most of the rooms on the first floor with drapes that can be pulled when desired. Rooms facing the rear of the building look out on the meandering creek with its duck population, and on a charming foot bridge which crosses the creek to land used for residents' personal garden plots. Rooms on the front of the building look out on the lawns, trees, and shrubs in that area. All these first-floor rooms have a light open feeling. And, if nothing else is going on; one can always depend on being entertained by the ducks. They are an integral part of life at the Manor.

There are two large patio areas. One opens off the hall in the corridor containing the poolroom, beauty shop, hobby room, and store--on this patio are lawn swings which comfortably accommodate several people. These swings are favorite gathering places on nice days. The other patio opens off the multipurpose room, and here is located.a large barbecue--the center of many summer activities either for the Manor as a whole or for individual groups.

There is ample parking space available for those residents who still drive their cars and eighty still do so. 


\section{THE STAFF}

The staff consists of the Manager, a resident registered nurse, bookkeeper, secretary, building engineer, and four janitors.

The Manager is a thirty-five-year-old man with a keen sense of humor who combines qualities of empathy and caring with those of a shrewd businessman. His respect for and interest in each resident is apparent at all times.

One small, soft-spoken elderly lady sitting beside me at a Civic Club meeting nodded toward the Manager and said in a rather timid voice, "He's a very nice man." I responded, "Why do you think so?" And she replied, "He always speaks--everyone doesn't, you know." She added that, "He has a very nice family too."

A former newspaperman whose college major was Business Administration, this man was "drafted" into becoming Manager of his first retirement home some ten years ago in Montana. After a successful five years as Manager there, he accepted the position as Manager at the Manor.

He believes the success of a retirement home is based on management and the structure of management. He quoted a success ratio of 95 per cent for the 202 program and said the failures have been because of bad management or bad planning at the outset.

This man, however, always uses the pronoun "we." When asked about this, he replied, "I have never done anything--you can't run a. project like this by yourself. It takes many, many people--it takes 
residents and staff. To work in public housing you have to be willing to give a lot of yourself, but without the rest of everybody functioning with me, then it's worthless:"

His goal is "to have the best managed and the best operating retirement home in all respects that there is in the United States-and possibly the world."

This Manager believes nothing is more important than detail. Thus, files are color coded, there is a monthly analysis of income from different areas, and the budget is within three per cent every year because he knows exactly the way finances are running.

In addition, he knows the background of each resident, including physical ailments and which member of the family will be most concerned and best to work with in case problems arise. Careful recording is done in residents' files of falls, mental aberrations, and so forth, so that if it becomes necessary to discuss these with residents or family, documentation is available.

He meets with the Board of Directors yearly and submits a monthly report to an attorney who is the liaison for the Board. He prefers to have a free hand in managing the home rather than having to contend with people who don't "know the business." Therefore, he was hired on the premise that "if I do a good job, leave me alone--if. I don't, fire me."

Staff meetings are described as open and freewheeling. Staff relations seem good and though the Manager describes himself as "probably a hard guy to work for"--in part because of his concern. 
with detail--staff members speak highly of him. For example, one person told of the Manager's concern about dangers of fire and water damage and his semi-annual inspection of residents' apartments for stacks of newspapers or anything that might present a fire hazard. His concern with water damage stems from sinks or tubs being forgotten and allowed to overflow. (Residents also spoke of feeling an added sense of security because of these inspections.)

The nurse is a lady in her early seventies who has held the position of resident nurse since the Manor opened. She carries an electronic pager and is on call twenty-four. hours a day. She deals primarily with emergency and short-term situations and does not provide day-to-day nursing care for residents who are ill.

When the nurse is away from the building, the staff handles emergency situations. The Manager's residence is located right across the street. Thus, he is readily available for emergencies. The nurse shares in social activities of the Manor and is in every sense a "participating" resident. Residents spoke highly of her and of ten mentioned feeling more secure knowing a trained person is handy to handle medical emergencies.

Other staff members whom I observed a good deal and talked with briefly demonstrated courtesy and respect toward residents. They seem to genuinely like the residents, and residents reciprocate this liking. For example, a motion was made and passed before the 
Anniversary Dinner that the Civic Club purchase tickets for the maintenance men and their families--"because they do so much to make our lives here at the Manor more pleasant."

\section{THE RESIDENTS}

Residents of the Manor range in age from 62 to 95 , the average age being 80.1. Most are retired, though approximately 2 per cent are semi-retired. There are presently 324 residents composed of 238 single women, 38 single men, and 24 couples.

Incomes are in the low to middle range, and one-third of the residents are eligible for housing subsidies under the federally financed low-income housing program. Of this one-third, 50 receive Federal Housing Authority (Section 23) assistance, and 50 are under the Federal Rent Supplement program. Thus, one-third of the residents pay approximately 25 per cent of their income for rent, and the remainder of their rent is paid by the federal government.

I was interested in whether there seemed to be stigma attached to being one of the residents receiving housing assistance. However, no one to whom I talked during my months at the Manor volunteered the information that he was receiving subsidized housing, and of the many people with whom I visited, only three mentioned that some residents do receive housing assistance.

I asked these three if they had observed any discrimination toward those people by other residents, and each said no, that no 
one would know it unless the persons themselves volunteered the information.

On the other hand, many residents remarked candidly that, "My income is limited." Or, "I can seldom afford to eat in the restaurant." Or, "My medical expenses have been high, and I really must watch my pennies."

Ninety per cent of the people living in the Manor have been residents of oregon for some years. Others moved here on retirement to be near relatives, or because they were attracted by Oregon's milder climate.

Residents tend to be working-class people with a sprinkling of nurses, school teachers, and two doctors. Thus, the Manor population is similar to that of the community.

Though residents of the Manor are up in years, they-are a sprightly group. Admission requirements are that they be physically and mentally capable of taking care of themselves. However, five are in wheelchairs and eleven in walkers much of the time-many because of conditions that developed after they came to live at the Manor. Most have various disabilities connected with the aging process, and a few require part-time help (either from relatives or paid help) with housework, laundry, or chores they are unable to manage for themselves. They are personally responsible for making these arrangements, however. 
One lady in her early eighties said; "In oụr group we never talk about our ailments or how we feel--all of us have something wrong with us--but we don't spend our time telling each other about it."

As stated before, eighty of the residents still drive their own cars. Some of these people are most generous about providing transportation to others in the Manor for doctors' appointments and other business engagements, or simply for outings. Now and then one hears a complaint such as, "I'm tired of freeloaders, so now I usually suggest we all take the bus." However, many of those with cars enjoy performing this sort of service for others and let it be known they are glad to do it for a small contribution toward the cost of the gas. 


\section{CHAPTER IV}

\section{THE PROGRAM}

\section{DEVELOPMENT}

Whenever a resident indicates interest in a particular activity, or indicates that he has some expertise in a certain area, he is given ample opportunity to discuss and develop it. And as ideas are discussed, they of ten gain momentum and develop into new activities.

The primary ingredient in development of this program, however, seems to be the atmosphere of acceptance and encouragement which enables residents to share themselves--their talents and abilities-with each other.

Program development will be discussed further in the descriptions of the various elements.

\section{PHILOSOPHY}

During the first few weeks I visited the Manor, several people mentioned the "turnover" there. Not wanting to ask too many questions but not understanding why there would be much turnover in a place where people seemed so content, I let it pass. Finally. I asked a lady in her early nineties, who has lived in the Manor since its opening seven years ago, what she meant by "turnover." "She 
looked astonished and said, "We11, my goodness, when you have a group of 350 people in our age range anywhere there's bound to be turnover--people die, have strokes and heart attacks, fall and break hips, then have to go to nursing homes--all that sort of thing--one expects turnover in any group of people in our age range!"

When a resident does become disabled and unable to care for himself to the degree that he is of constant concern to Management and/or other residents, he and the next of kin are contacted by the Manager. They are counseled about the situation, and other living arrangements are made. Management maintains a careful record of all incidents of falls, illnesses, and mental aberrations. Thus, these incidents are documented when and if it becomes necessary to counsel family and/or resident about the need to move. often, however, the resident comes to this conclusion independently when he realizes that he is no longer able to care for himself.

This policy seems to be very realistically discussed, accepted, and supported by residents, perhaps because it is clearly explained to the applicant and family members present during the application process.

In addition, people moving into the Manor express their desire to live the active years of their later lives in surroundings where they can be involved and active to the fullest extent possible (as most of them were in their younger and middle years). They are not ready for a nursing home atmosphere and do not want to live in one 
until it becomes necessary. However, several of them talked with me very realistically about "what I'11 do if and when. ..."

During one of our first interviews, the Manager stated:

The success of the project, and you base success on many things--a project can be said to be successful because it's full--but that isn't what I would say. To me, the success of a project is judged by how the people are functioning and how happy they are.

Thus, this Manager does not believe in having a paid social

director in a retirement home. It is his feeling that:

The residents' own committees should provide much of the scope and direction of activities, such as planned recreation and social events (forums, movies, dancing), as well as hobbies, arts and crafts and public and private banquets and meetings.

The Manager believes that among 324 people there is certainly going to be someone capable of creating, organizing, and managing almost any kind of activity. Thus, when someone comes to him indicating an interest in a new activity, his response is "sounds interesting--why don't you see if you can organize it." He says that once in a while someone feels he isn't helping enough to get something going, and his response is, "You may be old, but you're not incompetent." This in no way implies that this Manager is not involved. Quite to the contrary, he supports, cajoles, encourages, and gives public praise to individuals and groups for their efforts. He speaks often of the desirability of older people remaining active mentally and physically and continuing to be responsible people-responsible not only for themselves but sharing responsibility with him and each other for the quality of life in their home. 
He is thus a firm believer in activity and participation and is eager to have each resident involved to the extent of his abilities. He spends long hours meeting with groups and individuals and encouraging various clubs and committees. He attends social gatherings and is able instantly to call each of the 324 residents by name.' However, he feels for this to be truly these residents' home, they must share responsibility equally with him for it.

Therefore, it was interesting that I heard the Manager's philosophy reiterated often as I visited with residents, "Mr. Overgaard doesn't believe in a paid social director. He says that out of 324 people there should be talent available for any kind of activity we may want to start--and so far there has been!"

It is the Manager's belief that any retirement home could have this type of program and interaction given a commitment to it by residents and staff. He does believe, however, that it might be more difficult to start if one were working with a residential group accustomed to simply paying to have entertainment brought to them. It is his feeling that residents of the Manor may have been more accustomed to providing their own entertainment in years past.

The residents whom I queried about whether they thought this type of program would be as successful in another home--whether it could in effect be transplanted--were mixed in their opinions. Most thought the success of the program was a direct result of the Manager's willingness to spend evenings attending special functions (though he does not attend all regularly scheduled evening 
activities), to his desire that all residents have an opportunity to find companionship and stimulation in interaction with others, and to his total commitment and concern for the quality of life in the Manor. All recognized that this type of program requires a Manager and his residents sharing this commitment and working together.

This philosophy of involvement and participation was expressed recently in the Manager"s corner of the Manor News and Views (September, 1973, p. 3).

\section{ADMINISTRATOR'S CORNER}

Summer vacation has ended and the hustle and bustle of the scheduled activities at the Manor are again beginning to take shape. It is my firm hope that anyone who is able and capable of contributing anything to our social activities here at Westmoreland's Union Manor to please step forward. I.t not only gives the person who volunteers an uplift but also brings joy into your Neighbor's life for what you have given of your self. Participation has always been our by-line, and it does not matter how much you are able to participate, but even the assistance of making out Name Tags, baking a dozen cookies, or making Telephone Calls, all of your efforts are most welcome. If you do have anything to offer, please, as an active Resident of Westmoreland's Union Manor, come forward and volunteer.

\section{JWO}

It also is expressed in the following poem recently written by one of the residents, read at Civic Club, and included in the Manor News and Views (October, 1973, p. 4): 
OUR HOME

We live in a beautiful Manor

In the suburbs of Portland town

In a setting of awesome wonders

Like a maid in her loveliest gown.

With green lawns and trees in abundance

And a sparkling brook threading its way

Flowers in profusion and happiness galore

And our ducks who have all the say.

Clean walks and a patio awaits us

to ramble or swing as we choose

Our Lobby is cheery and inviting.

And you could if you wanted to snooze.

We've a pantry for our convenience

Well stocked with foods on the shelf

A dining room chefed by Jerry

With a cuisine for our good health.

We knit, we sew, we paint, we help

Our less fortunate neighbors with gifts

Because our hearts are full of love

And this gives all of us a lift.

A beauty parlor to keep us pretty

A pool room for our recreation

A Hobby Room with all the appointments

' $T$ is said the best in the Nation.

We have Jim and Ed and Kelly

To keep our house clean and sanitary

And Lara who manages the card games

With dignity and poise and caring.

Bingo on Monday nights and a movie on Friday

Keeps $\mathrm{Mr}$. Losher and his crew all a dither

Then we sing our hearts out on Saturday

Because we all have to get together.

Our apartments are clean and attractive

Our view simply out of this world

We worship on Sunday evenings

And on Holidays our flags are unfurled.

A salute to our nice Mr. Overgaard

Will make this poem complete

Our cup runneth over with blessings

Living here is really a treat: 


\section{ELEMENTS *}

Civic Club

Civic Club was organized by some 30 residents shortly after the Manor opened seven years ago. All Manor residents are considered members, and attendance at meetings presently averages 175 to 200 people. Meetings are held at 7 p.m. on the first and third Wednesday of each month.

Officers are elected annually from among the resident population, and to insure rotation of responsibility and leadership, there is a two-year limitation on term in office.

Election of Officers is held the First Wednesday in November. The Nominating Committee, which is appointed each year at a Civic Club meeting by the Manager (volunteers are requested before appointment of the committee is made), serves also as the election board. The number of votes each candidate receives is not publicized--only names of the persons elected to office are announced.

The Manager is Executive President of Civic Club. Other officers are the President, who conducts the meetings and represents the Manor at Westmoreland-Sellwood meetings on occasion; First VicePresident, who is responsible for visiting new residents, inviting them to Civic Club and introducing them, and for refreshments and entertainment once a month after the meetings; Second Vice-President, who is Social Chairman for the Manor; Third Vice-President, who is Health and Welfare Chairman and is in charge of floor monitors and sending cards to those who are il1; Secretary; and Treasurer. 
A critically important office is that of the Second VicePresident. She is responsible for arranging entertainment presented every second and fourth Wednesday evening, such as musical groups, school choruses, and talent groups; for all parties sponsored by the Civic Club; for the quarterly birthday celebrations (honoring birthdays of Manor residents occurring in the three-month period) and entertainment for these occasions; and for keeping supplies on hand for other groups to serve refreshments.

Committees are appointed to help the social chairman with responsibility for parties and dinners, and there are usually many volunteers for these committees.

Civic Club meetings are lively and contribute a great deal to the feeling of community in the Manor. Meetings follow a regular format: Salute to the Flag, reading of the minutes of the last meeting, report by the Treasurer, introduction of new members, and reports by the various committee chairmen and club presidents.

The meeting is then turned over to the Manager, and it is at this time that decisions and plans are made regarding functions sponsored by the Civic Club. (Subsequently, working out of details for. any function discussed in the meeting is left to a committee.) Decisions are made about subsidizing various activities, residents bring up complaints they feel should be discussed by the group, the Manager may read suggestions from the Suggestion Box kept in the lobby, and certain administrative problems such as energy 
conservation may be discussed, new legislation concerning senior citizens may be reviewed, or other items of current interest may be introduced.

The interaction in these meetings is spirited, and the Manager is adept at leading this type of interchange. Residents have their say, and sometimes feelings are intense,i.e., during a recent discussion over the six-foot-tall graphic art floor numbers recently painted on the wall facing the elevators on each floor; or whether to add to the cost of individual tickets for the luau by including barbecued pork on the menu; or whether to modify the manner in which birthdays are honored. However, compromises are reached when possible, or an administrative decision may have to be accepted. In any event, this discussion helps to "clear the air" and keeps life at the Manor dynamic and viable.

Civic Club is funded in several ways: from regular dues of twenty-five cents each month (approximately 290 of the 324 residents are dues-paying members); from each individual or group contributing ten per cent of any sale or money-raising effort; and from special functions, such as the semiannual Trifles and Treasures sale (to be discussed later).

The club finances entertainment and refreshments for parties it sponsors. This averages $\$ 75$ to $\$ 100$ for each function. For some parties, residents pay twenty-five cents each to help offset costs. These funds are returned to the Civic Club treasury to provide money for more activities. Another reason for the twenty-five cents per 
resident ticket charge is that it informs the social chairman how many people to plan for when she is buying refreshments. (See Appendix B for Civic Club Financial Report for 1973, and Appendix C for minutes of a Civic Club meeting.)

Men's Club

This club, also known as the 3-M Club (Moreland Manor Men), is comprised of all male residents, and about 35 attend regularly. Meetings are held on the first and third Tuesday of each month from 9:30 to $10: 30$ a.m. Members contribute twenty-five to fifty cents each meeting primarily to cover the cost of coffee and rolls, and this is a time of real conviviality for the men. Officers of this club are the President, Vice-President, Secretary, and Treasurer.

The Men's Club contributes greatly to life at the Manor. For example, the members sponsored construction of the outdoor barbecue, with the club purchasing material and the bricklayers' union donating labor. And after completion of the barbecue, they sponsored a "wienie roast" to dedicate it. They sponsor pancake breakfasts held in the dining room two or three times a year. They sell tickets for the breakfasts and also serve as waiters. The Gourmet Kitchen outdoes itself on these occasions with all. the fluffy hotcakes, sausages, syrup, and coffee one can eat. This club also sells tickets for the Thanksgiving dinner served by the Gourmet Kitchen.

The Men's Club sponsored the flag project. Residents purchased the flags, and the men installed holders on the balconies. 
The flags are flown on holidays and at other appropriate times. The Men's Club purchased the juke box, which is located in the large multipurpose room, and which has an excellent selection of music on it at five cents a disc. This provides music for dancing and background music during dinners. Proceeds from the juke box, which have totalled $\$ 1,980$ over the past four years, go to the Men's Club treasury which is used to provide more activities. Men's Club also provided indoor and outdoor shuffleboards, a new pool table for the poolroom, and sponsors pool tournaments throughout the year, as well as horseshoe and dart tournaments. They sponsor three nationality day parties: Spass Nacht (a German Fun Night party), Viking Day, and St. Patrick's Day. They also regularly contribute toward other projects, such as purchase of the grand piano or materials needed. by other groups.

They carried responsibility for purchasing feed for the duck population until early in 1974, when, due to the increased cost, they requested Civic Club to share this expense. This discussion provided considerable good-natured joshing and amusement at Civic Club when introduced.

As noted previously, the men are considerably outnumbered by the women at the Manor, and this club, which was organized four years ago, contributes markedly to the feeling of togetherness among the men. (See Appendix $D$ for minutes of two Men's Club meetings.) 
United Christian Fellowship

This committee is responsible for the weekly Singspiration, held from $4: 15$ to $4: 30$ p.m. Sunday evenings and for the Vesper Service which follows. Guest ministers are invited to speak at Vesper Services and often bring special musicians. Coffee is served after Vesper Service on the third Sunday of each month.

Attendance at regular Singspiration and Vesper Services averages 75 to 100 people. Periodically, the Christian Fellowship Committee sponsors special concerts in the multipurpose room, and attendance at these is usually 200 or more.

Some of those who attend Vesper Services Sunday evenings also attend the church of their choice on Sunday mornings. Other residents mentioned appreciating being able to attend church without leaving the building.

\section{No-Host Coffee Hour}

This activity, is held on the first Saturday of each month from 2:00 to $3: 30$ p.m. Residents of the Manor volunteer to provide cookies, and a charge of fifteen cents is made for coffee and cookies.

Entertainment is arranged by the Coffee Hour Committee Chairman. The entertainment chosen for this activity is always free of charge.

Attendance averages 135 to 150 residents, and several people mentioned that this Coffee Hour "provides a good opportunity for new residents to become acquainted." A few men share in Coffee Hour, 
but it seems more popular with the ladies. This activity was started about six years ago.

Manor News and Views

The Manor newspaper is being included in the social program because it is an integral part of the communication system at the Manor. The Park Bureau helped a group of four residents start the paper two years ago.

One man coordinates production of the paper, which consists of four pages with an editor in charge of each page. Certain types of news or certain organizations, such as Men's Club or the Administrator's Corner, are assigned to each page editor on a continuing basis. Each editor then fills in with whatever news he or she has of interest.

Two residents of the Manor type the stencils and another runs the paper off on the mimeograph machine. The four editors are responsible for assembling the papers. The paper is published on the third Tuesday of each month and is distributed on Wednesday morning before Civic Club meets in the evening.

Distribution of the paper is handled by the floor monitors. As previously stated, the Third Vice-President of Civic Club is the Health and Welfare Chairman and is in charge of floor monitors. Therefore, he distributes the papers to the two monitors on each floor (25 to each monitor). These monitors in turn push a copy of the paper under the door of each apartment. This method insures that each resident receives a copy of the paper. 
Residents look forward eagerly to the paper coming out each month, and it provides another link in the interaction within the home.

Recently the lady who has been front-page editor moved to another retirement home, which is being opened and managed by this same corporation, and some discussion ensued in Civic Club as to whether the office might take over her page. However, the Manager expressed himself as not in favor of this, preferring that it remain the residents' paper, published and managed by the residents, and the residents agreed.

Union Manor News, Sellwood-Moreland Bee

The Sellwood-Moreland Bee is the community newspaper mentioned previously. A Manor resident is responsible for writing news of activities in the Manor for this community paper. The paper is sold in the Manor store. A pile of papers is left, and a container is there to drop money into to pay for them. This, of course, contributes to interaction between Manor and community.

\section{Bingo}

This activity was started shortly after the Manor opened by the man, now in his early nineties, who continues in charge of it. Two other residents assist in conducting the games--one resident operates the machine and calls out the numbers, while another checks winning cards. Bingo is played every Monday from 7:30 to 9:00 p.m. with approximately 80 residents participating. 
Careful accounting is made of the money taken in by this activity, and the accounting is rechecked by. the Manager the following morning. These funds have paid for patio swings, redwood tables and chairs, and bridge tables, as well as contributing, along with funds from other groups, to many other "extras" for the Manor. Five per cent of the money received is retained for maintenance and replacement of the professional-looking equipment which was purchased in 1972 .

Movies

Movies are shown Friday nights at seven, and these are very popular, drawing 140 to 150 people each week. On three Friday nights a Travelogue is shown, and on the fourth Friday a full-length movie is shown.

Tickets are sold for the monthly movie and cost twenty-five cents each. The Civic Club subsidizes the movies; however, in the past year they have more than paid for themselves.

A movie committee composed of three people chooses the movie from a catalog. And another resident arranges for it to be shown on the Civic Club's own projector, screen, and sound system.

Cards

Cards are played on Tuesday and Thursday each week from 7 to 10 p.m. This activity was started shortly after the Manor opened by the same man who started the Bingo games. However, he asked a 
lady resident (now in her early eighties) to take them over about six years ago, and she still manages them.

This lady has a book of names and telephone numbers of about 150 card players and the kind of cards they prefer to play. Thus, residents who wish to join a foursome or who need an extra player to make a foursome can call her, and she arranges it for them. Other players make up their own foursomes and simply come and play. There is an average of 21 tables on Tuesday nights and 14 on Thursdays.' The cards chairman also holds afternoon games at times during the winter for those who wish to play. Bridge is most popular, but people also play canasta, pinochle, and other card games.

One resident made and donated card table covers; others have donated cards. The janitors set up tables and chairs for all activities such as these, sometimes aided by a few of the residents.

\section{Knitting Club}

This group was started some six and one-half years ago by a group of eight or nine ladies who knitted for the Boys and Girls Aid Society. The Society provided the yarn and received finished garments in return. This continued for two or three years.

Then the group wanted to "branch out a bit"--a resident donated twenty dollars to buy yarn, and the club started knitting afghans, stoles, pillow covers, and padded coat hangers. These items are sold at various sales within the Manor and to individual buyers as wel1. They also take orders for afghans and sell them. 
There is a display case in the hall near the multipurpose room where several groups as well as individual residents display handwork, and one may contact the resident who has charge of the case for instructions about whom to contact to purchase various items.

The padded coat hangers and afghans are particularly in demand. Chances are sold (twenty-five cents a ticket) almost continuously on afghans--one afghan at a time--and when about forty dollars has been paid in, a drawing is held to determine the lucky winner.

The Knitting Club has been highly successful financially, as well as providing many hours of companionship and activity for its members.

From its proceeds the Club has purchased, among other things, a grandfather clock, a light for over the directory, a gold oval mirror, and a coffee table for the lobby. It donated $\$ 150$ toward the recently purchased grand piano, and recently provided a threemicrophone loudspeaker system for the Manor that cost well in excess of $\$ 400$. The old loudspeaker system was donated to Marshall Union Manor, which is presently under construction and soon to be opened. Knitting Club, as do all groups, contributes ten per cent of its proceeds to the Civic Club treasury.

This group meets weekly on Thursdays from 2:00 to 4:00 p.m. Members, of course, also knit individually at other times. 
Sewing Club

Sewing Club started out six and one-half years ago sewing for the Boys and Girls Aid Society and later for Waverley Baby Home. However, the past three years or so they have made a variety of items for children, such as pajamas, play outfits, little girls' dresses, slips, T-shirts, baby quilts, and lap robes for Veterans Hospital patients. During the year 1973, this group made 144 garments and many baby quilts. These articles are beautifully made of remnants donated to the Club and of materials purchased with money donated to the Club. For instance, the Men's Club gave $\$ 50$ for pajama material, and the Civic Club donates money also from time to time for materials.

The Sewing Club ladies prefer not to sell. these items. "Therefore, some are donated to the Veterans Hospital Gift Shop, while most of them are donated to the clothes closet at a nearby church to be given to needy families.

Sewing Club meets every Monday from 2:00 to 4:00 p.m., and attendance presently averages 12 to 14 ladies.

Two ladies act as co-chairmen of this group, and members bring a sandwich and share their sandwiches and a cup of coffee before starting to sew. They meet in the hobby room, which is equipped with only one sewing machine, and this poses something of a problem. However, members can bring their own portable machines or save sewing that can be done by hand to. do with the group, then do sewing requiring a machine in their own apartments. 
This Club faltered recently, and membership dwindled to only five or six people, causing the chairman of the committee a good deal of concern, as both she and the Manager felt that Sewing Club had the potential for providing companionship and activity for some of the residents. However, the group had seemed to prefer simply coming to the meeting to pick up their materials, then doing most of the sewing in their own apartments.

Then the chairman of the committee, who had done an excellent job of coordinating activities of the group, requested that she be replaced because of $i l 1$ health. She was replaced by the two present co-chairmen, the social time of coffee and cookies (money for cookies was provided by Civic (lub) or sandwiches was instituted, added encouragement and publicity was given the group, and it is again flourishing.

This is an example of how the social program is supported by both residents and management.

Tri-Chem Embroidery Class

This group started about four years ago when a lady who had sold Tri-Chem embroidery materials moved into the Manor. They meet weekly in the Hobby Room on Tuesdays from 1:00 to 3:00 p.m. and at other times informally in the instructor's apartment.

The group averages 12 to 14 people, and its members make many beautiful items. One lady who was a talented oil painter has become 
so enthusiastic about Tri-Chem that she has given up painting in oils completely.

Periodically members have a display and sale of their work in the meeting room. These items are particularly in demand as gifts as well as for individuals' own enjoyment. And at a recent TriChem embroidery sale, members took in $\$ 163.20$, of which $\$ 16.32$ was given to the Civic Club.

Oil Painting Class

This class is held on Saturday mornings from 10:30 to 12:00. Members pay one dollar per week for lessons, and the instructor is a talented artist who is not a resident of the Manor. About six to nine residents participate in this activity, which started four and one-half years ago.

These paintings are displayed in the halls and various downstairs rooms of the Manor and add greatly to the homelike atmosphere. Several of the artișts told me they had never painted before taking this class, and though true, I found it difficult to believe because some of the paintings look quite professional. I suspect there are several incipient Grandma Moseses in the group.

These paintings are often sold and are, of course, also used as gifts by the artists. When one is sold, ten per cent of the sale is given to the Civic Club. 
Union Manor Tours

These tours are a popular feature at the Manor and are scheduled monthly throughout the summer and fall, though shorter tours are also scheduled at closer intervals. One of the Manor residents acts as Chairman of this activity with one other resident assisting. Transportation is arranged with commercial bus companies or airlines.

Recent tours have included trips to Reno, the new Jantzen Beach shopping center, Hawaii, Cottage Grove Steam Engine Train Trip, Lake Chelan and North Cascade area in Washington, Salmon Bake at Depoe Bay on the Coast, Ice Capades, and the Oregon State Fair.

The tours are much discussed before they take place and for weeks afterwards. They add variety and interest to conversation, both for those who go and those who stay at home and hear about them secondhand. In addition, they provide a way for residents to satisfy their desire to travel without having to be responsible for making all the arrangements. There is usually one bus load of 40 people and sometimes two bus loads of 80 to 90 people.

\section{$\underline{\text { Sing-Along }}$}

Residents say this activity "just grew like Topsy" out of the desire of some residents to sing together. It started shortly after the Manor opened and has developed into a regular Saturday night activity. It is held from $6: 30$ to $7: 30 \mathrm{p.m.}$, and approximately 70 to 80 residents attend regularly. 
One resident acts as Director, and two residents are responsible for playing the piano--one playing when the other cannot. Song books have been purchased with money donated by the Civic club. The program is changed from time to time, i.e., an instrumental or vocal solo, or a reading is given. An article on the Sing-Along in the Manor News and Views (December, 1973, p.'2) stated, "The time is 6:30 Saturday evening and all are welcome, whether you sing, whistle, hum, or silently beat time to the songs we loved so long ago."

Trifles and Treasures Sale

This is both a financial and social event. Held semiannually, it is one of the main money-making events of the year for the Civic Club. The September, 1973, sale brought in $\$ 319.59$.

Residents are asked to donate items they no longer want, use, or wear. One resident is in charge, and five other residents--one for each category--are in charge of individual sections. These sections and the amount made on them in the september sale are as follows: Kitchen $\$ 61.91$, Jewelry $\$ 25$, Food $\$ 93$, Clothing $\$ 77.40$, Miscellaneous $\$ 62.28$.

The items are displayed on long tables set up in the meeting room, and this year the lady who sells chances on afghans was there with her row of tickets as was the lady collecting donations for the piano fund. 
Residents contribute quantities of items to this sale, the merchandise is attractively displayed, and a good deal of interaction takes place centered around this activity.

\section{Pool Tournaments}

Pool tournaments are held several times a year and are a source of a good deal of friendly rivalry among residents. Only the men participate in these tournaments, and so far they have not accepted the challenge of playing against the ladies.

Twenty-one men played in the last tournament, named "Watergate" by its Chairman. And a steak dinner for all the players was held to honor the champion.

This tournament draws as many spectators as there is room for-both men and women.

Pool is a popular activity, and one often finds a pool game going on after Civic Club meetings, while others may dance awhile. Several residents mentioned "how nice it would be" if they had room for a second pool table.

\section{Landscape}

This is being included under elements of the social program because the grounds are a source of pride and interaction among residents. One lady in her late seventies has been in charge of landscaping the past six years. This, of course, is done in consultation with the Manager; however, residents attribute the beauty of the grounds to this lady and her "helpers" on the staff. 
Residents notice the various bushes and flower beds with interest, and several took me to see a shrub or tree they particularly enjoyed.

One resident and his wife have a large corner flower bed which they maintain, and this year it was planted with petunias that became a mass of glowing color and much admired by other residents. Another resident and his wife maintain one of the rose gardens on the grounds. Other residents have their own garden plots where they can raise flowers and vegetables as they desire.

Kitchen Band - "Manor Merrymakers"

This is a new activity at the Manor started in the fall of 1973. It has been an instant success. It started with about 15 residents, soon grew to. 37 , and now there is a waiting list. An article on the band in the Manor News and Views (October, 1973) stated, "We were sure there were many hidden musical talents in the building and sure enough, they are coming forward. Drums, mouth organs, triangles, cymbals, bells; and washboards . . . anyone can hum into a Hum-A-Zoo. Anyone wishing to join will be provided with one."

A resident donated money for a tambourine, and the group is presently looking for a guitar player.

One resident is the band leader, and two other residents are the pianists--one playing when the other cannot. The group has now purchased uniforms--1ong ruffled aprons worn with white blouses 
for the ladies and red vests and neckties worn with white shirts for the men.

A Name-the-Band contest was held with first, second, and third prizes given. A panel of judges was appointed, and the winner was announced at the Anniversary Dinner.

This group has performed at several Manor parties and is very enthusiastically received. And the Band is receiving more invitations to perform outside the Manor than it can accept. It has performed at nursing homes, other retirement homes, for church groups, and at Loaves and Fishes centers.

The teacher of the Tri-Chem embroidery class made a pennant for the Band, and one of the Band members wrote the following theme song. It is played and sung to the tune of "The Red River Valley." Come, gather around us, dear neighbors While we sing a melodious song, of the Manor, the ducks and the trimmings That make our days never seem long.

With our vests and our aprons so cheery And our bugles all primed and on guard, We are ready to give you our everything, And your approval our only reward.

\section{Crafts Class}

This class is held weekly on Friday from $2: 30$ to $5: 00 \mathrm{p} \cdot \mathrm{m}$. and is sponsored by the Park Bureau. A fairly new activity, the class has been held only about three months. Nevertheless, attendance averages 14 residents.

The instructor attended a Civic club meeting to tell about the various crafts she can teach--almost anything one could wish to 
learn--and to urge both meri and women to attend if the group wished to start a class at the Manor.

This class and the oil painting class are unique in that the instructor is not a resident of the Manor. However, both provide another avenue of involvement and participation for several people.

\section{Garden Club}

This is a new activity started in early 1974. It is being developed at the suggestion of a new resident with many years' experience with plants and flowers:

She is a lady in her late eighties who plans to share information on the care of house and balcony plants, their likes and dislikes, when and how much to water, what and how to feed, pruning, and other suggestions regarding plant care. Residents are urged to bring their plants to the meeting so that others can see their problems firsthand.

Considerable interest in this activity has been expressed, and 22 people attended the first meeting.

Good. Neighbor Day

Also a new activity, this Day is being started at the suggestion of a resident. It is tentatively planned for the occupants of odd-numbered apartments to ask the residents of even-numbered apartments down to the dining room for a cup of coffee on that day.

Residents seem enthusiastic about starting this as a way of promoting interaction among new residents and those who may as yet be uninvolved in some type of activity. 


\section{Special Events}

There are many regularly scheduled events held annually on special days. For example, a luau complete with barbecued pork is held in August each year. This dinner also celebrates the summer birthdays. This year the Civic Club subsidized tickets at fifty cents per resident.

There is a Fall Open House and Anniversary Dinner celebrating the birthdays of the fall months and the anniversary of the opening of the Manor. This is attended by the Board of Directors and many guests. A summary of the past year's activities is given by the Civic Club secretary during the program following the dinner (see Appendix E). Civic Club paid fifty cents each toward the cost of residents' tickets for the dinner this year. The dinner is prepared by the Gourmet Kitchen.

There is a November Fest or German party, a Viking Day celebration, St. Patrick's Day, Hallowe'en, and Valentine's Day parties, Christmas party complete with Santa (played this year by the Manager, to the residents' delight), New Year's Eve party, Fourth of July celebration, and Labor Day barbecue. Some of these are sponsored by the Men's Club; others by Civic Club.

Most of these are held in the evening; entertainment such as a musical, dance, or talent group is provided; refreshments are served; and the party is usually followed by dancing and a few people playing cards. 
At the Christmas party, residents bring a gift marked "boy" or "girl" to put under the tree, and these are given to the Firemen's Toy and Joymaker Group for distribution to needy children.

On Thanksgiving the Men's Club sold tickets to the Thanksgiving Dinner which was cooked by the Gourmet Kitchen, and 60 residents attended.

On Christmas Day a potluck is held. The Civic Club buys turkeys, which are prepared the day before by the kitchen. Early Christmas morning the Manager puts the birds in the oven.

Then each resident brings various dishes, and everyone has potluck dinner together. This celebration is eagerly anticipated, a committee to plan and coordinate it is appointed, and the dinner is delicious.

One resident remarked that she was surely not going to be away from the Manor this Christmas. She "wouldn't miss the Christmas dinner with my friends for anything!"

On New Year's Day, Speck's Chicken is purchased by the Civic $\mathrm{Club}$, and everyone has dinner together--each resident pays $\$ 1.25$ and one resident purchases and delivers the chicken. Then there are cards and dancing afterward.

The Anniversary Dinner attracted 263 residents and guests this year, the Luau 340, the Christmas party about 300, and the New Year's party about 250. Attendance at other parties held throughout the year averages 200 to 275 people. 
other activities held during the year are bake sales, candy sales, and pie socials. Also, pupils from schools who have entertained at the Manor during the year free of charge are allowed to sell candy for their fund drives in the Manor. (Other schools and organizations are not allowed to do this because the schedule will not permit it.)

Educational types of activities are also conducted, such as a Red Cross first-aid class. And to aid in maintaining residents' good health, a doctor was invited to speak at a Civic Club meeting about flu shots. Residents could sign up for these and for a fee of two dollars receive the shots at the Manor. (The doctor who spoke at Civic Club came to the Manor to administer the shots.) Also, 16 public health sessions have been held with different specialists as guest speakers.

In addition to formally scheduled activities, residents have many individual or small group activities going on. The list is almost endless, but a few illustrations will suggest the variety and scope of the informal activities. Several ladies make dolls of various types and sell or give them away. One lady has made 544 yo-yo dolls and over the years has had some sixteen ladies helping her. These have been given to the Veterans Hospital gift shop, the Firemen's Toy and Joy Makers' Christmas program, and as door prizes at the birthday parties and other special occasions.

Another resident collects eye glasses which are sent to the Blind Commission in New York and from there to places such as 
Guatemala and Mexico. Another resident, along with several recruits, wraps bandages to be sent to missionaries in various areas. This lady has also been active in the move to recycle cans, collecting and delivering them to the designated pickup location.

One lady bakes high-protein bread which she sells at cost to friends in the Manor; another has compiled a scrapbook of samples and instructions for various knitted lace patterns which will eventually be donated to a historical museum (knitting lace is a dying art); several residents mentioned enjoying studying a particular subject in depth, then discussing it with their friends; and, as mentioned before, one may see a couple or two dancing to music from the juke box at various times of the day. One man in his early eighties told. me he tries to dance daily. He remarked, "I enjoy it, and it helps keep joints flexible."

Residents filled four barrels with packaged food for the Police Department's Sunshine Division this year at Christmas time, and several work as volunteers in the Retired Senior Volunteer Program, the Red Cross blood bank, Cancer drive, and other community efforts.

Lawn bowling at nearby Westmoreland Park is also popular with some residents--both men and women. Westmoreland Park is the only place in this area with a lawn bowling green. Thus, people come from the entire metropolitan area to participate. A lady from the Manor won the lawn bowling tournament this year (and also met the man there whom she later married). 


\section{OPERATION}

The key to operation of this program is the Manager who wholeheartedly believes in the value of a program for which residents and Manager share responsibility. He, therefore, makes himself available to residents so that he quickly is made aware of suggestions they have for new activities, of problems that may develop, or of changes that may be indicated.

Staff is available as well, and it is a part of their duties to set up chairs for movies, meetings, and programs, and tables and chairs for cards and dinners. Several men of the Manor also help with this, but it is not left entirely to them as their responsibility.

Certain men of the Manor do, however, maintain responsibility for setting up the loudspeaker system for use at various functions. Another resident has assumed responsibility for making clever and attractive notices to publicize activities. These are posted on each floor just opposite the elevators and insure that each resident will be reminded of forthcoming activities.

In addition to the Manager's availability and his realization of the need for him to "stay on top" of this kind of program, residents who are officers of clubs and chairmen of committees devote many hours to planning and coordinating activities for which they are responsible. And this kind of devotion and dependability on the part of a fair percentage of residents seems essential in this type of program. 
The Manager is not present at each class or group activity, but he does drop in from time to time, and he may be seen playing a game of pool after Civic Club or challenging the winner of a game during one of the pool tournaments. He always attends Civic Club and Men's Club meetings, as well as special parties and dinners where he often acts as master of ceremonies.

Thus, operation of this program is not left to any one person and neither is it left to chance. All people involved seem to realize the importance of their contribution and the need for them to function in a highly dependable manner. Also, residents encourage and reward the committee members and club officers with warm and frequent expressions of appreciation.

Most of the classes and some of the clubs are suspended during the summer months, as is Sing-Along and publication of the newspaper. This is done to encourage residents to spend time out-of-doors and to have a change of routine. However, Civic Club, Men's Club, and Vesper Services continue, as well as parties, picnics, barbecues, and special festivities.

Orientation to the social program begins during the admission process. Applicants are requested to list activities in which they are interested on the admission form. Also, at the time they move in, they are given a list of activities and when they occur. In addition, recently a questionnaire was distributed to each resident in the home inquiring about his interests and desires as to new activities. 
By-laws have been written for Civic Club (see Appendix F). And it is in part because of careful attention to such details, which help guide future officers, that this program functions so smoothly.

Also contributing to the continuity of the program are the scrapbooks. These were started in 1967, and one lady is responsible for their maintenance. The scrapbooks contain pictures and mementos of various activities, copies of summaries of activities which have occurred each year given by the Civic Club secretary at the Anniversary Dinners, and other relevant items.

Copies of the Manor newspaper, or information regarding specific activities may be requested from the Manager.

\section{ASSESSMENT}

These present tenants and those preceding them over the past seven years have taken a structure equipped only with basic necessities and have made it a home. They have added lawn swings, patio furniture, card tables, pool table, hobby room and lobby furniture, and many other items as well.

And recently they raised $\$ 1,500$ in three months to purchase a grand piano for the multipurpose room. This money was raised entirely from individual donations, a pie social, and contributions from the various groups and clubs.

It is difficult to assess to what degree the social program as it developed added impetus to residents" desire to "fix up" their 
home. Hawever; the social program with its emphasis on involvement and sharing responsibility seems basic to the high degree of interaction present within the home.

A further outgrowth of the stimulus of the social program may be residents' pursuit of individual and small group activities. Perhaps emergy generated from one activity leads to more energy with which to enjoy other activities.

Perlaps it is an easy transition from becoming acquainted at clubs and parties to dancing at odd moments during the day with a few friends, and to rolling bandages or studying together.

Some residents' eyes are failing to the point where they are no longer able to do handwork or read. And for them sharing responsibility for glanning and carrying out various social activities seems doubly important as a means of keeping their minds alert and bodies agile.

Becatse of the scope of activities available, most residents should be able to find one or more that appeals to them. If not, due to the nature of the program, any resident can promote and help develop almost any activity in which he may be interested--and is encouraged to do so. One stipulation is, of course, that the activity be for the good of the residents of the Manor.

This type of program also seems to be a remarkable leveler because it relies heavily on personality, abilities, and talents of individuals rather than on their economic assets. 
The program functions amazingly smoothly--especially when one considers the number of personalities involved. In regard to this, one resident remarked that "Once in a while someone gets mad at someone else and doesn't speak for a day or two, but then it's all over, and they're friends again." The Manor motto is, "Active people are happy people," and these people seem to live their motto. 


\section{CHAPTER V}

\section{CONCLUSIONS}

\section{POSITIVES}

As stated before, this type of program gives residents a feeling of responsibility and involvement and leads to a feeling that this is truly their home and not just a building in which they live: Residents' independence is carefully fostered and encouraged, as is their privacy. Several residents remarked, "Although we do a lot of socializing, we still can always close our doors and have our privacy."--and they appreciated this. Some residents remarked, "On our floor we never visit from apartment to apartment unless we're asked." Others said, "On our floor, it's like a school dormitory all the time--we just tap on our friends' doors, and they're always glad to see us." Since these remarks often pertained to the same floor, I concluded these wère individual perceptions and that residents are quite free to live the life style most comfortable to each of them.

Both men and women take pride in their appearance and are attractively dressed and well groomed. This may be attributed in part to the individuals who live in the home. However, I suspect it also is a further outgrowth of the social program in the home. 
Residents are interacting with others on a regular basis and thus pay added attention to their own appearance and to that of others. Abdo (1973, p. 86) in a study of the personal and social adjustment of women in a suburban nursing home vs. those in urban high-rise public housing found " . . an equally strong relationship between personal adjustment and social adjustment at both types of residences, (which) supports Dr. William Glasser's supposition that, among the elderly, improved social involvement leads to better personal functioning."

Furthermore, the dependability of certain of the meetings occurring seems important. For example, Civic Club met as usual on the third Wednesday of November even though it was the night before Thanksgiving. This assurance of certain activities always occurring may contribute to a factor that I noticed among residents, i.e., I met no residents who seemed unsure. what day of the week or month it was. Having met many elderly people whose days seemed to "run together," this seemed rather remarkable to me. Cutler (1972, p. 383) wrote as follows: "The life satisfaction of the aged has been studied from a number of analytical perspectives (Adams, 1971; Riley and Foner, 1968). Among the most consistent findings are those which, contrary to the predictions of disengagement theory, show a positive relationship between life satisfaction and levels of social activity and interaction (Kutner, Fanshel, Togo, and Langner, 1956; Maddox, 1965, 1966; Palmore, 1968; Pihlblad and McNamara, 1965; Tobin and Neugarten, 1961)." 
This program seems to add further weight to those findings. In general, residents spontaneously express satisfaction with their lives. They are using talents and skills acquired over many years of living, and they have ample opportunity to learn new competencies such as painting, playing pool, and studying together. And some who "never learned, or had forgotten how to smile" are learning that. as we11.

\section{NEGATIVES}

The only negative I found in this home and its program was that of the lack of variety of food offered in the dining room.

If it were possible to offer more variety and a better quality of food on a regular basis, and at prices residents could afford, more residents would use the dining room. This would provide an added element of satisfaction and interaction in the home.

However, restrictions in the 202 program itself, as well as the financial situations of many of the residents which leave them limited funds for food, combine to create problems for anyone trying to manage the dining room facility. (See Appendix A, IV, p. 71, and Appendix G, 7 , p. 106, for further discussion of this point.)

I found no other negatives. I felt that all residents were accorded equal interest and consideration from staff members and that the degree of satisfaction residents expressed with the quality of their lives was outstanding. 


\section{LIMITATIONS}

I wondered if some of the men might enjoy a place to do woodworking. And a few of the ladies would enjoy another pool table so they could have more pool-playing time. I suspect this would lead to more ladies playing pool. However, these are primarily structural limitations and would have involved adding more rooms in the building when it was planned.

I found no limitations in the social program. People who do not participate choose this as an option rather than having it forced upon them.

A few people remarked: "In a place such as this, one can't get too involved--I have a few good friends and that's enough."

A few attend no formally scheduled activities such as Civic Club meetings but do attend and very much enjoy the parties.

others are involved in many activities and with many people. Thus, how one lives.in this home is very much a matter of individual choice rather than one of limitation in the program itself.

\section{THE LESSONS FOR SOCIAL WORK}

The elderly no less than the young need the social and psychological support of other human beings. Yet many live out their last years in Ioneliness and isolation.

Some choose to remain in situations no longer suitable for them because they fear a move to a retirement home. others on very 
limited incomes cannot bring themselves to accept low-cost housing. because of the stigma they feel is involved. Still others have moderate incomes but are unable to find housing suitable for their physical needs and are also unable to pay the large down payment required in many retirement homes. They would like very much to live in a home such as the Manor, but too few are available. Thus, a large percentage of the elderly, in part because of their housing situation, are vulnerable and succumb to the onslaughts of old age far sooner than may be necessary. These problems are discussed by Eckstein, 1973; Kral, 1973; Rao, 1973; and Rudd, 1973.

The people of the Manor and their program demonstrate the possibilities that exist for a better, more fulfilling life for the elderly than many of them are now experiencing. They demonstrate what the elderly can accomplish for themselves and for others given an environment congenial to their needs. Furthermore, they have accomplished this without social workers, psychologists, therapists, or social and activities directors. Thus, rental costs are kept within a range that people with lower incomes can afford.

In addition, they are demonstrating that the low-income elderly (who in many instances were not in the low-income class during their working years) need not be segregated in "low-cost" housing. They are demonstrating instead that a "mix" of low and middle income groups can prove very satisfactory for both. This mixing of income groups might also help dispel the notion that "retirement homes are the ghettos of the future." 
Life in a retirement home surely would not appeal to--or be necessary or feasible for--all elderly people. Yet it seems a most satisfactory option for some.

The problem, however, is not only one of educating the elderly and their families to consider this as an option rather than as a "last resort." The problem lies as well in the slowdown of federal mortgage funds with which to build homes such as these.

For example, during the year 1973, funds for retirement home housing programs (202 and 236) were cut entirely for an eighteenmonth period, bringing construction of housing specifically tailored to the needs of the elderly to a virtual standstill. When and how these building programs will be resumed is uncertain at this point. Instead, the government proposes to supply more money for the rent supplement program. However, this program, though necessary, is no substitute for housing built specifically for the elderly. In a paper (see Appendix G) delivered at the Conference on Housing and Environment for the Aged sponsored by the Gerontological Society at its annual meeting in 1971, the Manager of the Manor stated a fact known only too well by those social workers who work with the elderly poor in our inner cities. He said that:

A growing number of older people are being pressed into high density living situations due to economic, medical, dietary, social, and transportation needs. Numerous senior citizens lack the usual options to deal with their own needs and have experienced a greatly reduced freedom of choice.

Later in the paper he stated that " . . the talents and capabilities of today's elderly must not be underestimated." He is 
thus keenly aware of both the restrictions faced by and the potential of today's elderly people.

Another person, who is a resident of the Manor and who is front-page editor of the Manor News and Views, also realizes the potential of life for the elderly. And she wrote. a Christmas wish (Manor News and Views, December, 1973, p. 1) to her friends in the Manor as follows:

AN AWKWARD CHRISTMAS CARD WISH -

I know what you are thinking. This page will never fit in with ather "normal" cards in your Christmas basket. I must admit shape is not the only awkward factor involved. The wish is equally out of place. I know you'd be more at home with a HO - HO - HO and sparkling glitter which could be vacuumed up after the holidays. But within this awkward card I wish for you, more than any single blessing, a year that is creative and fulfilling you as a person and completely unconventional in every way. May you reach out and feel the freedom of a butterfly: a year full of grasping hidden talents. Reach out and love, look into souls, create. I apologize for lack of sleighbells but my wish is may you truly be yourself in the year ahead.

This lady (who is presently in her early seventies) and the Manager expressed their conviction, a conviction that I hope is shared by us all, that the later years of life can be creative fulfilling years: And it seems these years can be creative and fulfilling if they are lived in a setting conducive to satisfaction and growth, and with people who believe there is more to be found in old age than senility.

What are the lessons for social work?

We can join hands with people such as those described in this paper--including the elderly themselves--who are working to promote better housing for the elderly. 
We can assume an activist stance in keeping government informed of the need for a multi-faceted approach to housing for our poor and middle income elderly. And hopefully government will respond by freeing funds for construction of housing such as the Manor.

We can help educate our elderly clients and their families in regard to the advantages and disadvantages of various types of retirement living, thus helping them make informed choices among the various options available in our communities. And, hopefully, as all citizens become more aware of the need, options will be available. Finally, we can expect and encourage our elderly to be innovative, to nurture and develop their own abilities and those of their friends. It is true that some elderly people suffer incapacitating physical disabilities. But many want and continue to be capable of initiating and developing their own activities--of continuing to manage their own lives--particularly if given the proper setting. Hopefully, in the years to come the elderly will not lack. options and will not have to "experience a greatly reduced freedom of choice."

Hopefully, all elderly will have the opportunity for years of living that are "creative and fulfilling in every way"--years of sharing themselves--such as those being experienced by residents of Westmoreland's Union Manor. 
SELECTED BIBLIOGRAPHY 
Abdo, Edmund, Joseph Dills, Harriet Shectman, and Mary Yanish, "Elderly Women in Institutions Versus Those in Public Housing: Comparison of Personal and Social Adjustments," Journal of the American Geriatrics Society, XXI (February, 1973), 81-87.

Adams, David L., "Correlates of Satisfaction Among the Elderly," Gerontologist, XI (Winter, 1971), 64-68.

Brody, Elaine M., "Aging," Encyclopedia of Social Work, 1971 ed., I, 51-74.

Carp, Frances M., "Effects of Improved Housing on the Lives of Older People," in Middle Age and Aging, Bernice L. Neugarten, ed., Chicago, University of Chicago Press, 1968.

Cutler, Stephen J., "The Availability of Personal Transportation, Residential Location, and Life Satisfaction Among the Aged," Journal of Gerontology; XXVII (July, 1972), 383-389.

Eckstein, D., "Common Symptoms and Complaints of the Elderly," Journal of the American Geriatrics Society, XXI (October, 1973), $4 \overline{40}-\overline{443}$.

Glasser, W., Reality Therapy, New York, Harper and Row, 1965.

Hartman, Chester W.; "Housing: Local and State Agencies," Encyclopedia of Social Work, $1971 \mathrm{ed.,} \mathrm{I,} \mathrm{612-617.}$

Hess, Julian, "Housing: Federal and State Programs," Encyclopedia of Social Work, 1971 ed., I, 606-612.

Kral, V. A., "Psychiatric Problems in the Aged: A Reconsideration,". Canadian Medical Association Journal, CVIII (March, 1973), 584-589.

Kutner, B., D. Fanshel, A. M. Togo, and T. S. Langner, Five Hundred Over Sixty: A Community Survey on Aging, New York, Russell Sage Foundation, 1956.

Lawton, M. Powell, Frances M. Carp, Marie C. McGuire, Kermit K. Schooler, Maurice B. Hamovitch and James E. Peterson, and Aaron Lipman, "Housing for the Elderly--A Symposium," Gerontologist, IX (Spring, 1969), 9-38. 
Maddox, G. L., "Fact and Artifact: Evidence Bearing on Disengagement Theory," Human Development, VIII (1965), 117-130.

, "Persistence of Life Style Among the Elderly," Proceedings of the 7 th International Congress of Gerontology, vienna, Viennese Medical Academy, 1966.

Mathiasen, Geneva, "Housing for Special Groups," Encyclopedia of Social Work, 1971 ed., I, 636-643.

Newcomer, Robert, "Environmental Influences on the Older Person," Geriatrics, XXVIII (July, 1973), 120-128.

Palmore, E. B., "The Effects of Aging on Activities and Attitudes," Gerontologist, VIII (Winter, 1968), 259-263.

Pihlblad, C. T., and R. L. McNamara, "Social Adjustment of Elderly People in Three Small Towns," in Older People and Their Social World, A. M. Rose and W. A. Peterson, eds., Philadelphia, F. A. Davis, 1965.

Plutchik, R., M. McCarthy, B. H. Hall, S. Silverberg, "Evaluation of a Comprehensive Psychiatric and Health Care Program for Elderly Welfare Tenants in a Single-Room Occupancy Hotel," Journal of

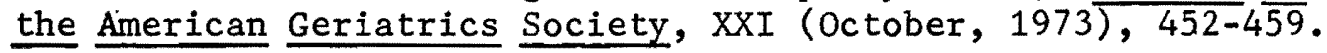

Rao, Dodda B., "Problems of Nutrition in the Aged," Journal of the American Geriatrics Society, XXI (August, 1973), 362-367.

Riley, M. W., and A. Foner, Aging and Society: An Inventory of Research Findings, New York, Russell Sage Foundation, 1968.

Rosow, Irving, "Housing and Local Ties of the Aged," in Middle Age and Aging, Bernice L. Neugarten, ed., Chicago, University of Chicago Press, 1968.

Rudd, T. N., "Mental Disturbances in 0ld Age," Journal of the American Geriatrics Society, XXI (August, $1 9 7 3 \longdiv { , 3 4 2 - 3 \overline { 4 5 } }$.

Sherman, Susan R., Wiley P. Mangum, Jr., Suzanne Dobbs, Rosabelle P. Walkley, and Daniel M. Wilner, "Psychological Effects of Retirement Housing," Gerontologist, VIII (Autumn, 1968), $170-175$.

Stein, Joseph A., "Laura Olson: From Baker to Bangkok--A Study in Population," Northwest Magazine, pp. 8-11, in the Sunday Oregonian, June 17, 1973. 
Tobin, S. S. and Bernice L. Neugarten, "Life Satisfaction and Social Interaction in the Aging," Journal of Gerontology, XVI (April, 1961), 344-346.

Zampella, A. D., "In Support of the Natural Sociological Environment for the Elderly," Journal of the American Geriatrics Society (April, 1973), 172-174. 
APPENDIXES 


\section{APPENDIX A}

\section{RESPONSES TO QUESTIONS}

I. What were your reasons for moving into a retirement home? Answers given most frequently to this question were:

1. Wanted to live where I could socialize without having to drive or take a bus across town--or go outside in bad weather.

2. Inability to maintain home--repairs, etc.

3. Convenience--"I don't even have to go outside to put out the garbage!"

4. Desire to live alone where could be independent of family yet maintain contact with them "without their having to worry about me."

5. Loneliness and a feeling of isolation. "Wanted to live where I could get help if I needed it."

II. How does this location work out for you?

Response was invariably, "How could one possibly find a handier location--bus stop at the door, lawn bowling and golf a few blocks away, parks close by, store in the building if I want to use it, etc.?"

III. How much interaction is there between Manor residents and the community? 
None saw much interaction with the community other than mentioning the "nice bus driver," "the nice clerk at the store," etc. Several mentioned they felt the Westmoreland business community was "glad to have the business of 350 more people." Three mentioned that a few people speak when out working in their lawns as they walk by, and one mentioned a person who gave her bouquets of flowers a time or two. A few mentioned community people using the restaurant facilities now and then.

IV. How often do you eat in the dining room?

Only a small. percentage of residents eat regularly in the dining room, and the dining room was often the subject of complaint. "Prices too high," "little variety in menu," etc. Several residents mentioned the problem, however, that the dining room cannot advertise for business to add customers so that it could afford more variety and lower costs because of increased volume. (The dining room is leased to a man who is also allowed to use the facilities for wedding .receptions to help make it a paying operation.)

It seems unfortunate that many residents in subsidized housing now enjoy adequate living quarters, but with costly medical needs and other expenses, must exist on perhaps $\$ 20$ per month for food. If these people received a subsidized food allowance as well, enabling them to utilize the restaurant more often, the restaurant would have increased business and could no doubt become more competitive. 
Only about 25 per cent of the people eat in the restaurant. And approximately 2,500 meals are served in an average month.

Some residents with more income, and who still drive, go out to eat fairly often, however. And a year or so ago a resident committee was formed to negotiate with the man who leases the restaurant facility to try to promote better menus and prices. No one seemed to feel this committee has been able to effect significant change.

Some residents have dietary limitations, and it is more satisfactory for them to cook for themselves, while others simply enjoy cooking their own meals. There are also many impromptu and planned "pairings" for cooking and eating meals in each other's apartments or going out "Dutch treat."

v. How do you spend your leisure time? Have you started new activities since coming here to live, or are you continuing activities you enjoyed before coming here to live? Many residents have started to paint since coming to the Manor who have never painted before in their lives. They attribute this to an oil painting class conducted since 1969. Many of these paintings are hung in various downstairs rooms, some are sold, and others are given to relatives and friends. From my observation, there are several incipient Grandma Moseses in the Manor because of the talent displayed.

Several women have learned to play pool since coming to the Manor and are sharp pool players. One of these ladies, age 80 , who 
plays pool regularly, said, "I never had a chance to learn before coming here." This lady is also presently knitting her 37 th and 38 th afghans.

Leisure time activities are discussed more completely in the section on the social program itself--formal and informal.

VI. Do you feel cut off from your family and friends?

This question was asked in various ways, hoping to avoid the function of denial. However, no resident admitted to feeling "cut-off" from faraily or friends. Most of the residents mentioned frequent visits with family and grandchildren during the course of their conversations with me--visits both at the Manor and in the children's and grandchildren's homes.

One resident mentioned that "when it snowed so hard last year, my daughter said she was so relieved to know I was here and that they didn"t need to try to drive 20 miles to dig me out of the snow!" This same lady had told me earlier that when she announced her decision to move into the Manor to her family, they protested, "Oh mother, you're not ready for that kind of living." She says now they're beginning to realize it's probably one of the most satisfactory decisions she's made.

Many residents expressed their pleasure in being able to visit with family, yet not be dependent on them--they liked having their own social activities and friends within easy access in the Manor. One lady laughingly said, "I'm going down to my daughter's over 
Thanksgiving, but I've got so much going on here that I'm going to stay home for Christmas!"

Another lady volunteered, "Of course, we'd all like to see more of our children but they have their lives, and we have ours, and that's the way it should be. This way we get together because we really want to, but I'm so busy here with my own activities. . ." Then she listed how she spends her time. Another expressed the feeling that she's "glad I don't have to 'keep up' with a younger family."

VII. What advantages do you see in retirement home living?

Among the advantages mentioned by the residents were:

1. Companionship--the opportunity to associate with people without even going out-of-doors is appreciated.

2. Security--the knowledge that the building is fireproof is important to most residents. "It's concrete you know, and if something did catch fire, I could keep the doors closed and go out on the balcony and wait for help."

3. Monitor system--"knowing someone is checking regularly to see that I'm all right means a lot to me." "Each resident on moving in is given a knitted ring with a tassel that fits over the doorknob. This is placed outside on the doorknob at night, and at eleven each morning designated floor monitors check each door. If they find a ring not taken. in, the office is called, and someone checks to see if the resident is all right.

4. Emergency help--the fact that there is a nurse who lives in the building and is always on call for emergencies is comforting.

5. Safety--the security of knowing other people are close by minimizes concern about burglaries and break-ins. Residents also mentioned the fact that knowing the 
maintenance man is working in the building throughout the evening hours gives them a feeling that "someone is looking out for things."

6. Convenience--the absence of physical barriers is especially appreciated by those who use wheelchairs and walkers. They are also keenly aware of how isolated and how dependent on the help of others they would be if they were living in a home alone. They can be "truly independent here."

7. Transportation--the availability of bus service at the front door permits easy access to the broader community. Many residents said they were "so grateful that I don't have to depend on someone else to take me places."

However, the advantage mentioned most often was the social aspect. "I can play Bingo every Monday night, cards on Tuesday and Thursday nights, there's always some sort of entertainment on Wednesday nights, always a show on Friday night, the Sing-Along on Saturday nights, and Singspiration and Vespers on Sunday nights--plus all the other activities going on"--and plus the informal socialization. VIII. What disadvantages have you found in retirement home living? Disadvantages mentioned were few. The one most often mentioned had to do with size and location of the refrigerators which are located under a kitchen counter top and are too low for many residents to lean over and see into. Several residents have had platforms built and set the refrigerator on these platforms; then they use the space under the counter for storage. Some have purchased their own refrigerators, or families have purchased small freezers to supplement the refrigerator (though this doesn't solve the problem of having to get down on the floor to see into the refrigerator). 
One person mentioned the need for a freight elevator because when people move in or out everything has to go through the lobby. In addition, when someone becomes ill he must be transported in the regular elevator and through the lobby.

Three persons mentioned they very much missed being able to step out their back door to their yard and flower gardens. These people found being able to have a small plot of ground a poor substitute for the freedom of having their own flowers and lawn only a step away.

Many mentioned the restaurant which has previously been discussed.

These disadvantages, however, most people pointed out, had to do with structural kinds of problems or an administrative limitation such as the stipulation in the federal loan that the restaurant cannot be supported from rental monies, and neither can it advertise. Thus, it is difficult for it to be competitive as to prices and variety of menu and so attract a larger clientele.

No one admitted to a disadvantage of living in the retirement home as such (other than the three who missed having their own flowers and garden "right out the back door," and this of course might have been a problem for them living anywhere other than in their own home).

A few felt the Manager "pushes" involvement in activities too vigorously, but in the next breath said they liked knowing when they wanted some social activity, it was available to participate in. 
I talked with a few people who because of physical disabilities seemed to prefer not to be involved at all. However, most of these people had friends in the building who visit frequently (they mentioned how nice it is to have their friends handy where they can "drop in"), and these had chosen their noninvolvement as an option rather than having it forced upon them.

It was interesting that others with equal, and in many cases more disabling handicaps (one man uses oxygen almost constantly and carries the tanks with him in an over-the-shoulder arrangement), never miss a Civic Club meeting, a Men's Club meeting, or a party, so this is very much an individual matter.

IX. Some people feel one may lose his independence if he moves to a retirement home. What do you think about that?

The response most often given was, "Oh, you don't lose your independence, you gain it!" This question was also covered in prior responses to previous questions asked.

Three remarks seemed to sum up residents' attitude toward the Manor. The first was from a tall imposing lady in her late seventies who said:

People learn to smile here--maybe they never had learned how before, or maybe they'd forgotten how--you know many of us had lost mates, had worries about trying to keep up our homes, had various illnesses that kept us from getting out much--but they come here and begin to get acquainted and get interested in something, and pretty soon you see them start to smile--and before long they start to seem young again. 
Another lady in her early eighties said she had started the practice of residents calling each other by their first names. She was one of the early residents, and she reminisced:

Not long after I moved in I went up in the elevator with a lady who was about 110 , and she introduced herself, then added, 'Call me Sally--I've been called Mrs. Smith for the last 55 years, now I want to be called Sally again.'

She said the lady died not long after that but that she had never forgotten her desire to be called by her first name. Thus, she had started the practice and "now almost everyone is on a firstname basis." This lady, who is the long-time chairman of the card committee, said she has a list of some 150 card players all listed only by their first names, telephone number, and a letter indicating the kind of cards they prefer to play.

People in this home make a real effort to know and remember each other's names. Whether this has stemed from the Manager's knowing each resident by name, I don't know, but it certainly seems to contribute to the interaction in the home.

The third comment came from the man who manages the restaurant. He said:

You'11 find this the best run, best managed retirement home you' 11 ever find anywhere. It's really amazing to see how people change when they come here. Often when they first come they're sort of closed in, then after while they get acquainted and are more friendly, and then they seem to be really enjoying their lives again.

He added, "Of course, we have some pills, but that's true anywhere." 


\section{APPENDIX B}

WESTMORELAND'S UNION MANOR CIVIC CLUB FINANCIAL REPORT NOVEMBER 1, 1972 to NOVEMBER 5, 1973

INCOME

Cash on hand November 1, 1972

$\$ 334.23$

CASH RECEIPTS:

Dues

727.85

Donations

31.00

Donations (Piano Fund)

70.00

$10 \%$ of Bazaars and other sales

130.52

Coffee Hour

183.92

Rent of loud speaker

6.00

Christmas Light Tour (c) 25c

26.50

Fun Fund Raising \& Candy Sales

650.37

November Treasures \& Trifles 1972

300.68

April

278.10

September " " " 1973

319.59

Speck's Chicken on New Year's

198.00

Movie tickets sold

273.50

March Bake Sale

115.00

Christmas Party refund

25.08

New Year's Party refund

50.52

Valentine Party refund

24.58

Refreshments refund

10.32

Sing A Long refund

6.58

July Party refund

13.45

Ladies Barbecue Party

54.15

Luau refund

Pie Social for Piano Fund

5.50

Gourmet Kitchen for Piano Fund

132.00

Miscellaneous refunds

30.30

6.75

$\$ \longdiv { 6 0 4 . 4 9 }$

\section{EXPENSES:}

Coffee Hour

Eleanor Duffern (entertainment)

$\$ 145.00$

20.00

Lobby furniture

244.00

Heath \& Sons (Candy Sale)

297.60

Christmas Party

100.00

New Year's Party

150.00 
Expenses continued

Speck's Chicken

Gourmet Kitchen (Christmas turkey)

Tri-Met (Christmas Light Tour)

Lora Handasyde (Prizes, etc.)

Fishel's (Patio Furniture)

January Birthday Party

Electric Clock

Coffee Urn

3 Thermo Serving Pitchers

St. Valentine Party

Sing A Long

Plywood \& hinges for cupboard doors

Britannica Year Book

Sewing Club donation

$\$ 198.00$

25.00

135.00

8.00

225.85

50.00

11.00

29.95

21.99

20.00

25.00

11.30

10.35

50.00

April Birthday Party

30.00

Lion's Club Candy

20.00

Luau supplies

59.35

July Luau Party

60.00

Piano Fund (Transfer)

70.00

Donation to Piano Fund

100.00

Luau subsidies a $50 c$

68.50

Anderson reception

Southeast Seniors Inc. (Dues)

31.73

5.00

Oregon-State Council (Lifetime dues)

25.00

September Entertainment

43.27

Kitchen Band (Manor Merry Makers)

25.00

Pie Social for piano fund

7 th Anniversary tickets (9)

132.00

31.50

Anniversary subsidies (163)

81.50

W.M. Piano Fund (Gourmet Kitchen)

30.30

Birthday Gifts

70.16

Movie Door Prizes

42.00

Refreshments \& Supplies

258.25

Manor News \& Views supplies

79.97

Get Well Cards \& postage

10.22

Miscellaneous expenses

$\$ \frac{23.62}{\$, 345.81}$

Total Expenditures

Total cash collected

Total expenditures

Balance No. 5, 1973

$\$ 4,004.49$

$3,345.81$

Submitted by: Fred W. Nitzel, Treasurer

November 5, 1973

Published in the Manor News and Views, November, 1973. 


\section{APPENDIX C \\ Westmoreland's Union Manor Civic Club}

February 6, 1974

(Fictitious initials have been substituted for names.)

The Feb. 6 th meeting of the Civic Club of Westmoreland's Union Manor was opened by Pres. L. B. who led us in the flag salute. The Secretary's report was read and approved.

A. G.; Treasurer, reported a balance of $\$ 369.91$.

S. T. introduced new residents Mr. \& Mrs. W. in $\equiv_{12} 122$.

M. L., Social Affairs Chr. thanked all who attended and all who helped make the Birthday Party a success. A refund of $\$ 19.20$ was returned to the Treasurer. On Feb. 13th the Jesuit Glee Club will entertain us and on Feb. 27 th a group of young people (Multiple Talents) of all ages will be here with their Director B. E. C. S., chr. of the Community Concert Series reminded all to save their stamps and for their convenience a container is placed in the meeting room. The sale of these stamps through the Church World Service buys food for needy children in 10 different countries. If you are interested in buying season tickets for six very exceptional concerts held at the Civic Auditorium please contact Mrs. D. 
E. G., Monitor and Welfare chr. sent her report on get-well cards issued. Mr. X. read this report. Six cards were sent since the last Civic Club meeting.

V. L., chr, of the Vespers Committee reported on speakers for the next two Sundays. She invited all to a Youth Choir concert from West Linn Baptist Church to be held on Feb. 24th.

F. C., chr. of the Sewing Club introduced Mrs. N. who is in charge of the Sellwood United Methodist Church Clothes Closet. Mrs. N. gave a brief history of the Clothes closet and what it means to the needy of our community, She thanked the Manor for the generous contributions of clothing and other hand made articles and said that there was a need for adult clothing.

Mrs. C. had on display hand made articles of clothing as well as quilts, etc. The audience had an opportunity to see this display following the meeting.

J. D. reported on the progress of the Painting Class as well as on the Arts and Crafts group.

Mr. M. invited all Scandinavians as well as others to a Travelogue on the coming Friday evening. This is by way of being something special.

S. G., chr. of the Movie of the Month announced the title of the next full length feature. It will be "Big Red" a story of a boy and his dog. It has a very impressive cast of actors and will be held on Feb. 22nd. at 7:30 P.M. There will be dollar door prizes and tickets will go on sale at times indicated by Mrs. J. 
H. J., Pres. of Men's Club invited all residents to the St. Patrick's Party to be held on March 15th. K. T. is in charge of entertainment.

R. W., chr. of the No-Host Coffee Hour commented on the record crowd attending the last coffee Hour. She thanked all who came and all who helped her serve, make cookies, etc. She gave The Band credit for luring some of the overflow. crowd. Next Coffee Hour will be held on March 2nd at 2 P. M.

E. C., Editor of the News and Views reminded all the Committee when the next meeting would take place. A temporary substitute for A. L. is functioning.

K. N., chr. of Treasures and Trifles again reminded ail residents that Thursday, March 7 th would be the next sale. This sale will be held in the meeting room between the hours of $10 \mathrm{~A}$. M. and $4 \mathrm{P}$. M. She urged everyone to save items for her.

P. B., chr. of the Manor Merry Makers Band gave an interesting report on the progress of the Band. She enumerated the engagements that had taken place and some that were to come. A Thank You letter was read from E. P., social chairman for the Baptist Manor and the Senior Fellowship of 1st Baptist Church, thanking all participants in the Band for the two performances.

L. G., chr. of the Manor Garden Club reported that attendance was good and interest high at the two meetings held so far. If you have a problem with a house plant, bring it to the next meeting and 
it will be discussed and a remedy found if possible. Watch for dates on the bulletin board.

Mr. Overgaard came to the Podium.

He congratulated those in charge and those who had helped to make the Birthday Party such a success.

Veterans and Veterans' widows were reminded to file for Home Owners Tax Refund. An additional check is due them plus the one they received in December.

A majority of the audience voted affirmatively to have music played before the Civic Club meetings.

Mr. Overgaard congratulated The Band on its progress and will omit the $10 \%$ return to Civic Club on its sales and money making projects. Mrs. T. will do some checking on available busses to transport The Band to its engagements. Two generous persons offered their cars for transportation.

Trips and tours from the Manor will be discontinued for the. present. In case there is a special request please see B. C. and perhaps it can be arranged. The Odyssey Club of Gresham has a set up that makes competition impossible. Owning their own fleet of busses and hiring retired drivers enables them to charge fares below what we would have to charge to break even.

Anyone interested in heading up the Knitting Club or the Good Neighbors Day please see Mr. Overgaard. 
A bill for $\$ 45.30$ for the repair of the movie projector was submitted by Mr. Overgaard. Mr. E. made the motion and Mrs. T. seconded that this bill be paid. Vote was unanimous.

J. B., Administrator of the Marshall Manor was introduced and in turn Mr. B. introduced three residents from Marshall Manor who had come with him to observe our meeting. Mrs. Q., Mrs. Y. and Mrs. A. were made welcome. Some of the hi-lites of Marshall Manor were shared with us. March 10 th is Open House Day there and we are all anxious to see for ourselves. Meeting adjourned at $8: 25$ P. M.

Signed F. M. Secretary

Signed W. L. Executive Director 


\section{APPENDIX D}

\section{M.M.M. Club Meeting}

Nov. 6th 1973

(Fictitious initials have been substituted for names.)

In the Chair

L. N. Members Present 36

Minutes prepared by the Secty, were read and ordered approved. Treasurer $T$. reported having seen A. C., who seemed to be making good progress and hoped to be at the next Meeting. He asked T. to express his thanks and appreciation of the nice cards and all the good wishes conveyed to him while in the Hospital.

Treas. then read his report of receipts and expenses since last meeting in Oct. showing a cash balance on hand of $\$ 231.84$. J.B. Collections since installed $\$ 1862.70$. B'day greetings were sung for B. $\mathrm{H}$. L. M. stated that the plans for the German Fest Party to be held on Nov. 30 were being co-ordinated. Fine entertainer C. S. - singer, yodeler, and accordionist, has been signed up.

V. N. reported that plans for Steak Dinner had been completed with A. D. and would be held on Nov. 14 th, Wed, at $6: 30$ P.M. Price $\$ 5$ per head. He called for members who planned to partake - sign up with him at the end of this meeting. 
L.M. read a note of thanks from F. G., one of the 3 winners of $\$ 5$ door prizes given by our Club.

Chairman asked Treas. to make a check for $\$ 5$ to $K$. V. winner of the last Pool Tourn.

W. S. spoke of the desirability of getting the Manor Hall Ways aired out once or twice a day. He made a motion, with 2 nd by F. S. that B. F. line up 2 men on each floor to thus aerate the hallways. Carried and so ordered. Mr. Overgaard stated that the Anniversary Dinner was a big success with the largest attendance ever - 247. Also that the Halloween party was very well handled and a very enjoyable evening for all. He expressed his deep apprec'n of all the men and women who worked so faithfully to obtain such fine results. He touched on the Oil situation for the Furnace. Said he hopefully believed that the J. Oil Co. would be able to supply us during the winter months. He added that the Manor Furnace required 250 gallons per diem on the colder days. Some members on the floor asked that a party again be organized to visit the Roof. Mr. Overgaard stated that if enough interest was generated, he would be glad to conduct the trip. Chairman asked L. N. to continue his fine work with the Sunshine Barrels - after a voice vote declared wholeheartedly to renew this fine custom.

$$
\text { N. F.B. }
$$

M. E. C. Secty. 


\section{Meeting of the $3 \mathrm{M} \mathrm{Club}$}

Tuesday Dec. 4th'73

(Fictitious initials have been substituted for names.)

In Chair L. N.

Members Present (33)

Sec. read the minutes of the previous meeting. No exceptions ordered approved.

Treasurer read his report for the intervening period - resulting in

a present balance of $\$ 154.64$ - J.B. gross collections $\$ 1892.70$.

Club welcomed Mr. B. to membership and chairman expressed pleasure at having him with us.

B'day greetings sung to H. L. - same being led by G. M.

L. M. reported on the very satisfactory results of the German Fest Party - sponsored by the Club which garnered an attendance of over 200 people.

C. S. the accordionist and yodeler was in great form and elicited much praise for her performance.

Mr. Overgaard congratulated L. M. for his masterful handling of the Fiesta held Nov. 30. L. M. attributed its success to a number of willing helpers - both men and women. 
He said in his opinion the Pool Table might well do with a new cover. Floor discussion resulted in this question being deferred for later (MUCH LATER) action.

He mentioned that Mrs. E. has been carrying quite a load as social Chairman and he wondered if the Men's Club would take over the Christmas Party, relieving the Civic Club. This gave rise to some agitation from a number of members and after a somewhat lengthy discussion - a motion was made by $W$. with a 2 nd by $S$. - that a committee be appointed to originate and put into effect - various ways and means to help the Civic Club in every way possible. Motion carried and Chair appointed S. and $\mathrm{P}$. to supervise such activity. M. F. was asked by the Chair to confer with Mrs. E. for erection and decoration of two Xmas Trees, one for Lobby, one for All Purpose Room. They were expected to be delivered on or about Dec. 14th. A.M.

M. F. said he would be glad to cooperate. N.F.B. Chair ordered ADJ. $10: 35$ A.M. M. E. C. Secretary 
APPENDIX E

High Lights of 1973

It seems that the past year has been a short one. Could it be because we are all getting older? However, getting older has many compensations. If we weren't as old as we are, we wouldn't be living in our beautiful Manor. And beautiful it is, indeed, both inside and out. Our lawn has never looked so green and well groomed. The beds of lovely geraniums have been enjoyed by everyone, whether passing by on the walk or sitting at a dining room table. One tree was especially favored by having a ring of geraniums and marigolds at its base and it reminded one of a ruffled collar on the gown of a fine lady of the past. Roses, everyone's favorite, bloomed profusely in their bed in front of the patio. Then, to top it all, there was the bed in the northwest corner. In the early spring it was filled with a "host of yellow daffodils," like the ones the poet wrote about. When they were gone, petunias took their place, beautiful pink and white petunias that were not only lovely to look at but they shed their perfume all around.

Many of the residents have been busy all year on worth while projects. More than 700 coat hangers were made and sold by the knitting group - this in addition to afghans and many other items. With some of their money they purchased the beautiful mirror that: 
hangs above the table in the lobby as a complement to the magnificent grandfather's clock, purchased last year. Their latest gift to the Manor was a new and very complete loud speaker system.

The sewing club is another busy group. This past year they made crib quilts and garments for needy children. One member, alone, made 70 little dresses. These items are given to the "Clothes Closet" of the Sellwood Methodist Church for distribution. Four barrels placed in the lobby at Christmas time were filled with food for distribution by the Sunshine Division.

At our annual Christmas party, each resident placed under the tree a gift for a child. With these gifts (there were eleven boxes of them) we helped the Toy and Joy Makers play Santa Claus to 11,104 needy youngsters.

Eye glasses were collected and sent to "Eye Glasses for the Needy" organization.

Donations of money and hand-made articles were given for the Veterans gift shop at the Veterans Hospital.

Our very capable tour chairman planned many enjoyable trips for us. There were the Ice Capades, the tour of Christmas lights, the Singing Christmas Tree at the Civic Auditorium, Kahneeta, Cottage Grove with a ride on the steam engine, San Juan, The State Fair at Salem and the salmon bake at Depoe Bay. Perhaps the trip enjoyed the most was our day spent in Seattle, where we had lunch at the Space Needle and a visit to the "Four Freedoms" retirement home. They really rolled out the red carpet and gave us a grand welcome. 
After entertainment and refreshments we were taken on a tour of the building. There were a few things that, we will have to admit, we wished we had, but on the whole we wouldn't for anything in the world trade our home for theirs.

One event always looked forward to, especially by the men, is the pool tournaments. This friendly, good-natured rivalry takes place several times a year. Last Spring, one winner was presented with a $\$ 24.00$ pool stock, compliments of Sheehan's Pool Company.

Lawn bowling is becoming increasingly popular with some of the women as well as the men. In fact, the tournament resulted in a woman being the champion, having won five straight games. And that isn't all she won. She is our most recent bride. Actually Cupid has been on the alert this year which shows that we are never too old because love knows no age.

We have had fun at our annual parties, Christmas, New Year's, Valentine's, St. Patrick's Day and our fourth Viking Day party. And now lest others be envious of the Irish and the Scandinavians, a German party is in the planning. The men have also sponsored a couple of pancake breakfasts and a fund-raising party. As a result of all this, new patio furniture was purchased--an electric clock for the Meeting Room, a coffee percolator, three thermal pitchers, and plastic tablecloths for the refreshment tables.

The treasures and trifles sale met with its usual success, as did a bake sale. 
One very welcome addition for our pleasure and good eating was the building of an outdoor barbecue. Much credit and thanks for this go to some of the men residents and to the bricklayer's union who donated the brick and the labor.

Another addition was the installation of a telephone booth on the outside near the front entrance.

We all enjoyed free bus rides during Senior Citizens Week in May, the courtesy of the Tri-Met Company.

In May the men's club sponsored a flag project. The residents purchased the flags and the men installed them on the balconies. Two hundred fifty flags were installed and they were flown for the first time on Memorial Day. It was a beautiful and impressive sight that inspired favorable comments from many of the neighbors and passers-by and even in a newspaper clear back in New Jersey. At a recent meeting of the Civic Club, representatives from the Veterans of Foreign Wars presented to the president of the men's club a beautiful plaque in recognition of the club's efforts in this project. They said the flying of so many flags from the balconies was an inspiring and patriotic sight.

Perhaps the greatest and most worth while project we have ever had was the purchase of our beautiful new piano. At first it seemed like a mammoth undertaking that never could be accomplished. But there it stands, magnificent proof that with enough determination and cooperation nothing is impossible. 
Our very latest undertaking is the organization of a Kitchen Band. We were hoping they would make their debut today. A "name the band" contest has been going on and a little later today we will find out the name the judges have chosen.

Many more interesting things could be said about the events of the past year, so here is a toast to our patient and good-natured Administrator, who always seems to have our welfare in mind, to the Executives who have done so much for us, to all those who work to maintain our home, and to each resident, a group of really great people. 


\section{APPENDIX F}

\section{BY-LAWS}

1. This Organization shall be known as the WESTMORELAND'S UNION MANOR CIVIC CLUB.

2. The purpose of the Club shall be to promote, in various ways, the happiness and well-being of its members, and to co-operate with other Organizations for the purpose of enhancing the welfare of Senior Citizens everywhere and to further other altruistic aims.

3. There shall be a meeting of the club on the first and third Wednesday of each month at 7 p.m., unless otherwise designated.

4. All meetings of the Club shall be conducted in accordance with Robert's Rules of Order.

5. All occupants of apartments in Westmoreland's Union Manor shall be eligible for membership in the club by virtue of residence in the House, and shall be considered a member, whether or not they participate in any of the Club's activities. Also, the House Administrator shall be a member by virtue of his position.

6. Anyone may be present at its meetings, as a guest, or as an advisor.

7. All members of the Club may be assessed a membership fee of $25 \mathrm{c}$ a month payable at the first meeting of the Club each month, but 
payment shall be voluntary, and withholding them shall not prejudice the standing of any member.

8. The officers of the Club, to be elected by ballot for a term of one year, to take office the first Wednesday in November, shall hold office no more than two consecutive years. To be effective at the forthcoming election, officers shall be as follows:

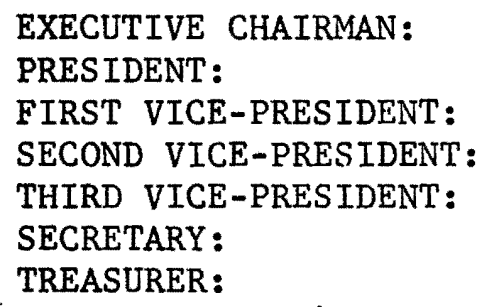

9. Duties of the Executive Chairman:

1. To appoint all Club Committees, except the three Standing Comnittees, and to name Chairmen. He shall be entitled to sit-in whenever he may choose, at any of their meetings, and to participate in them as a Member.

2. To encourage and co-ordinate the activities of all committees.

10. Duties of the President of the Club shall be as follows:

1. To call and conduct the meeting of the Club in accordance with customary procedures.

2. To perform any other functions usually accruing to the Office of President. 
11. Duties of the First Vice-President of the Club shall be:

1. To serve in place of the regularly elected

President in case of that Official's inability

to serve for any reason.

2. To serve as Chairman of the Membership Committee, to name its other members, and to appoint any subcommittees of that committee.

12. Duties of the Second Vice-President of the club shall be:

1. To serve in place of his superior officers in case of their inability to serve for any reason.

2. To serve as Chairman of the Social Affairs Committee, to name its other members, and to appoint any sub-committees.

13. Duties of the Third Vice-President of the Club shail be:

1. To serve in place of his superior officers in case of their inability to serve for any reason.

2. To serve as Chairman of the Welfare Committee, to name its other members and to appoint any subcommittee of that committee.

14. Duties of the Secretary shall be:

1. To keep accurate minutes of all meetings of the Club.

2. To act in place of the elected officers of the Club in case of their inability to act for any reason. 
15. Duties of the Treasurer:

1. To collect and safeguard all funds belonging to the Club, or held by the Club, and to render an accounting of such funds at each meeting or whenever requested by the President or Executive Chairman of the Club by membership.

2. To act in place of the duly elected officers of the club in case of their inability to act for any reason.

3. To exercise any other functions customarily exercised by a Treasurer.

4. The Executive Committee shall consist of all Officers and shall have discretion in dispersing funds in case of an emergency, and to report at the following meeting.

5. All funds dispersed shall be through our checking account, requiring dual signatures of Treasurer and Executive Chairman.

16. There shall be three standing committees as follows:

1. MEMBERSHIP COMMITTEE: Whose Chairman shall be First Vice-President of the $\mathrm{Club}$ and whose duties sha11 be:

1. To welcome and to introduce new members.

2. To promote attendance at Club meetings by posting notices or by personal calls. 
2. A SOCIAL AFFAIRS COMMITTEE: Whose Chairman shall be the Second Vice-President of the Club and whose duties shall be:

1. To organize and arrange for social affairs.

3. A WELFARE COMMITTEE: Whose Chairman shall be the Third Vice-President of the Club and whose duties shall be:

1. To keep informed about the health and needs of members and try to be of help to them.

17. Twenty-five members or more of the Club present at any meeting shall constitute a Quorum.

18. These BY-LAWS may be amended following the reading on any proposed Amendments at two consecutive meetings of the Club and an affirmative vote of a two-thirds majority of the Members present at the meeting to which the proposed Amendment is finally passed upon. Voting by Proxy only if a Member is too ill to leave their apartment.

A. B., Chairman

S. L.

J. H. 


\section{APPENDIX $G$}

CONSIDERATIONS IN PLANNING HOUSING FOR INDEPENDENT ELDERLY: AN ADMINISTRATOR'S VIEW

Paper presented in San Juan, Puerto Rico, Dec., 1971

by

James W. Overgaard, Administrator, Westmoreland's Union Manor

The numerous considerations that affect successful housing for the elderly are broad and complex. During the past few decades the Government and a few interested professionals have made an attempt to develop an adequate housing program for our twenty million older Americans. The Federal motto has been: "Safe, Sound, Sanitary Housing" which is certainly important but only begins to cover the necessary basic needs. A growing number of older people are being pressed into high density living situations due to economic, medical, dietary, social and transportation needs. Numerous senior citizens lack the usual options to deal with their own needs and have experienced a greatly reduced freedom of choice. As concerned professionals we must make a firm commitment to do our utmost to see that these needs are clearly identified and met. This nation's elderly built this country and now deserve care, comfort and consideration. There are many considerations that should be made to develop a successful housing project. In the balance of this paper, I will 
attempt to elaborate on some of the important issues, as I see them speaking for myself and as President of the Pacific Northwest Administrators Association.

1) A direct information and referral service concerning availability of program funds and technical assistance could be of great benefit if established. Better coordination of HUD regional offices is certainly called for. A careful study needs to be made of individuals and organizations that exploit senior citizens. Funds should also be made easily attainable for construction of housing alternatives, such as semi-care facilities and nursing homes at a low rate of interest. However, it is felt by many that these facilities should be independent and physically separated fiom retirement homes. The "campus" style living complex has been featured lately, but many regard this design to be undesirable.

2) A strong consideration should be made by the sponsoring organization as to what type of elderly people are expected to live in the housing project. Due to their background and experience-occupation, sex, race, geography, general health, life style, etc., there may be certain identifiable general needs that should be anticipated for each project. The expected type of residents should be a prominent factor in determining the site, physical plan, and even the number of units. The advantages of a social mix should be explored. Sponsors should construct housing projects in an area where a majority of the local residents were established including neighbors of relatively similar economic and social background. In short, project 
residents should find themselves located in an area where there is a general consensus of interest and harmony relative to their earlier lifestyles within the community.

3) Space surrounding the building(s) should be adequate for exercise, gardening, outdoor social activities and quiet sitting. Adequate (but not overabundant) resident and visitor parking is also important. Direct access to public transportation, shopping center, banking, medical facilities and entertainment are important community assets which can assist the elderly person remain more independent and connected with the local community.

4) In the past few years, the design features of housing facilities have developed and improved immensely for the convenience of the elderly. Some of the small, but important, items that should always be included are the following:

a) overflow drains in kitchen and bathroom;

b) lever type handles for door knob and plumbing;

c) light fixtures in the walls low enough for the resident to safely change by themselves;

d) adequate and convenient storage;

e) electrical plug-ins four feet above the floor;

f) peek holes in the front door, and a host of other conveniences.

Additional guide lines need to be established to include:

a) building standards and funding structure review; 
b) a mandatory service elevator independent of the passenger elevators and large enough to facilitate the use of stretchers, wheel chairs, furniture, and in emergencies. It should open on a private exit with direct access to a service entrance.

c) security problems are growing, especially in public housing and require immediate attention.

d) Strong consideration should be given to allocating at least $25 \%$ of floor space to non-revenue producing areas to be utilized for activities, storage, medical assistance, physical therapy, waiting rooms, communal dining space, and social service facilities. A great deal of of the success of any project stems from having adequate space designed for these non-revenue producing functions. In the past, an insufficient amount of space has been allocated to projects, thus stifling or eliminating many potential programs and services in order to make the operation financially feasible.

5) A thorough and complete review of the qualifications of staff for a housing facility (especially concerning a retirement project) is most important. Regardless of the satisfactory design of the building, the quality of the staff determines how successfully a housing program can be run for the benefit of the residents. Management is the key interface between tenant need and the hardware of the plant. 
a) Prior to the completion of the project, a qualified manager should be hired. It is a good policy to include the manager in the early decision making process and even retain an experienced manager as a development consultant. The manager must be a person who can directly relate to the elderly with genuine interest, understanding and sincere compassion. The administration of an Elderly Complex requires consistent dedicated service. The manager has the full impact of responsibility for the welfare of each resident balanced with the necessity to run an efficient operation.

b) The building engineer should have an exceptional knowledge of the physical and mechanical structure systems of the building. This includes crisis as well as routine situations. Where possible, it is helpful to bring the engineer in during the late construction phase.

c) The office personnel should be especially compassionate individuals with an abundance of patience. The size of the office staff varies as to the size of the project. The personal touch is of utmost importance when dealing with this age group. The resident should know that the staff cares and is dedicated to their welfare. However, the talent and capabilities of today's elderly must not be underestimated. They should not be over protected. Each problem, no matter how large or small has to be 
handled specifically, rapidly, and thoroughly. Trained food service, recreation and social service personnel must be screened for their ability to work with the older people. Participation in local, regional and national continuing education programs and association meetings are of great benefit and should be expanded. The staff should be regularly briefed as to the operation of each department in order that all are aware of the complete operation and the goals of service.

d) Tenant and neighbor volunteers combined with part time resident work can be a good way to provide personal service and keep staff costs down. As with any group, management should be careful to avoid favoritism.

e) A tenant council can provide a valuable interface and a source of feed-back between staff and resident. Activities can be co-sponsored, grievances discussed and policies evaluated. The resident population represents a vast source of under-utilized energy and experience which can be of mutual benefit.

6) Complete information as to application procedures, admittance qualifications, degrees of acceptable dependence and reasons for termination, should be clearly defined in order that staff, residents, and families may have a complete understanding of the requirements. These guide-lines are difficult to enforce, requiring experienced judgment and continual evaluation. Any resident requiring a 
consistent reliance upon the staff or other residents should be required to find other type housing. A meeting between the prospective resident and a member of their family as to the policies governing residence is necessary. With this understanding, the new resident of the independent housing project is assured of being with a group of progressive, alert seniors, and they would in no way want to contribute to a change in this atmosphere. It should be noted that a greater range of housing alternatives must be produced for those who require some limited care.

7) A grave injustice is being done by not providing an adequate diet for those who cannot afford or are unable to prepare it. Some strides have been taken in the field of housing, but malnutrition of the elderly continues to be a major problem. The importance of an adequate diet cannot be underestimated. I have dealt with the problems of the elderly for a number of years as manager of housing facilities both with and without mandatory food programs. Many low-income individuals with Social Security as their only income can often barely afford housing. I urge that a national food program be constructed to run parallel with the present successful Federal Rent Supplement Program to deal with this situation. The subject is controversial and requires further research. An adequate program of meals would be a great contribution to the health and wellbeing of thousands of elderly.

8) The Pacific Northwest Administrators Association composed of Administrators of 202 and 236 projects lists a membership of 
individuals from all walks of life: printer, storekeeper, policeman, army colonel, clergyman, housewife, etc. In the early 1960's when housing for the elderly was' just becoming a reality, sponsors were reaching into all walks of life to obtain management talent. This was successful in many cases, but due to the increasing complexity of management, specialized training in management for the elderly has become a necessity. Many recent project failures can be attributed directly to inexperienced management. I would recommend a series of fully accredited regional education centers be designed, including an active continuing education program for practitioners. At the present time, several universities have limited programs which should be expanded and broadened. Research is needed to measure the effectiveness of these programs as well as the ingredients of successful administration.

We must be realistic! In most 236 low-income housing projects including housing in general, economics is a major factor. Educators must orient the future administrators with the facts and figures that will indicate the things to expect upon assuming administrative duties. A good program for the development of administrators is a one year internship on the site of an accredited facility. This gives the administrator an opportunity to budget his fiscal year for an additional employee on a cost-sharing basis and plan a comprehensive training session. A realistic training program for new personnel coupled with better facilities will do much to keep step with the ever increasing needs in the field of housing the aged. Providing old people with the shelter and services they need is a most satisfying career and an attractive second career! 